\title{
CIVILIZAÇÕES URBANAS E TEORIAS DA CIDADE
}

\author{
URBAN CIVILIZATIONS AND CITY THEORIES
}

\section{Marconi do Ó Catão ${ }^{1}$}

\begin{abstract}
Resumo
Este texto discorre inicialmente sobre as relações existentes entre o indivíduo, a cidade e a sociedade urbana, buscando uma adequada compreensão sobre as concepções que envolvem a estrutura e as transformações das cidades. Assim, tomando o processo de industrialização como marco referencial para o surgimento das cidades atuais, este texto se propõe a desenvolver um estudo das teorias das cidades, com ênfase nas tendências contemporâneas. 0 objetivo central deste estudo é analisar a formação das cidades nos vários períodos históricos, desde a antiguidade até os dias atuais, enfatizando a origem das cidades brasileiras. O método de procedimento adotado foi o descritivo-analítico, no intuito de realizar uma abordagem entre as áreas jurídica, social e urbanística. Então, apresentamos uma retrospectiva das várias formas de desenvolvimento das cidades, cuja falta de planejamento acarreta sérias repercussões nos campos sanitário, ambiental, econômico e, especialmente, social. Os estudos realizados permitiram concluir que com a chegada do progresso técnico e da civilização industrial, a visão tradicional é superada, multiplicando-se, assim, os problemas com os quais uma cidade se depara: crescimento demográfico, condições de habitação da população e, sobretudo, enriquecimento de determinados extratos sociais, que se traduz pelas consequentes desigualdades sociais que comprometerão grande parte da população.
\end{abstract}

Palavras-chave: Cidade; Urbanismo; Sociedade; Planejamento Urbano.

\section{Abstract}

This paper first discusses the relationship between the individual, the city and the urban society, seeking a proper understanding of the concepts that involve the structure and transformations of cities. Thus, taking the process of industrialization as a reference point for the emergence of today's cities, this paper proposes to develop a study of the theories of cities, with emphasis on contemporary trends. The central aim of this study is to analyze the formation of cities in various historical periods, from ancient times to the present day, emphasizing the origin of Brazilian cities. The method of procedure adopted was descriptive- analytical, in order to implement an approach between the legal, social and urban areas. Then, we present a retrospective of the various forms of development of the cities, whose lack of planning has serious repercussions in the health, environmental, economic and especially social fields. The studies showed that with the arrival of technical progress and industrial civilization, the traditional view is overcome, thus multiplying the problems that a city faces: population growth, housing conditions of the population and especially, enrichment of certain social strata, which translates the resulting social inequalities that compromise much of the population.

Keywords: City; Urbanism; society; Urban Planning.

1. Doutorando em Direito da Cidade, pela Universidade Estadual do Rio de Janeiro/Universidade Estadual da Paraíba (DINTER); Doutor em Sociologia, pela Universidade Federal da Paraíba; Mestre em Direito, pela Universidade Federal do Ceará; Professor do Departamento de Direito Privado do Centro de Ciências Jurídicas da UEPB. E-mail: moct@uol.com.br 
INTRODUÇÃO

$\mathrm{Na}$ atualidade, a análise da cidade torna-se cada vez mais complexa pelo fato de outras temáticas passarem a fazer parte da agenda deste estudo, ou seja, questões ambientais, invasões de áreas protegidas legalmente, surgimento de loteamentos clandestinos, a problemática do destino final dos resíduos sólidos e a violência urbana são apenas alguns aspectos inerentes à discussão sobre a cidade. Sem dúvida, tudo isso faz parte do rol de desafios que a cidade, sobretudo a metrópole, tem de enfrentar no mundo contemporâneo. Ademais, associados a essa pauta de debate, focos antes poucos explorados se insinuam por meio das atuais características do processo de modernização - vias de circulação, arquitetura de edifícios, meios de comunicação, déficit de moradia, localização dos conjuntos habitacionais, etc.

No mundo antigo, cidade e urbe não eram sinônimos, pois enquanto esta era o lugar de reunião, ou mesmo o domicílio, aquela era associada à religião e à política. Além do mais, era notória a presença de um cerimonial simbólico vinculando o homem à cidade. Logo, um conjunto de valores materiais e imateriais distinguem os habitantes de uma cidade em relação a outras, dotadas de nome próprio e origem, ligando assim o indivíduo à cidade. Por sua vez, a sociedade urbana geralmente é designada como qualquer cidade: a grega, a oriental ou medieval, a comercial ou industrial, a pequena, média ou megalópoles, em uma conceituação complexa, tendo em vista que em geral não são consideradas as relações sociais (de produção) inerentes a cada tipo urbano. Mas, neste trabalho nos nortearemos a partir da compreensão de que a sociedade urbana é aquela que nasce com o processo de industrialização.

$\mathrm{Na}$ conjuntura contemporânea, a cidade vem sendo estudada a partir de seus processos de formação e transformação, como também de sua estruturação interna, sendo essa tarefa dificultosa, pois envolve as dimensões da vida social, econômica, política e cultural. De fato, as práticas sociais, em especial, são partes integrantes de um conjunto de determinações que constituem a base das relações entre a cidade e o meio urbano; consequentemente, a cidade não se resume ao conjunto de edifícios com variadas finalidades de uso ou mesmo ao conjunto de ruas por onde circulam pessoas e veículos, nem tampouco ao território ocupado, diversamente, pelas pessoas em suas atividades econômicas e culturais. Indiscutivelmente, a cidade é bem mais do que cada um desses aspectos, pois ela vai além da simples articulação entre eles. Então, na análise da cidade, é preciso fazer um retorno no tempo, em busca de sua gênese, bem como realizar uma análise das variadas manifestações urbanas da época atual. 
Portanto, a cidade exterioriza os interesses e as ações da sociedade e, concomitantemente, oferecendo condições para que tais práticas se concretizem, contribuindo, assim, para a determinação do próprio movimento advindo dessas ações.

Em 2001, em cumprimento à vigente Constituição Federal brasileira, foi aprovado o Estatuto da Cidade (Lei no 10.257/2001), que não estabelece o conceito específico do que seja cidade, remetendo às Câmaras Municipais a fixação das delimitações territoriais de suas cidades, objetivando a estruturação das bases para os Censos Demográficos realizados periodicamente.

Neste texto, procuraremos contextualizar cidade produzida e transformada pelas relações capitalistas de produção por ocasião da primeira Revolução Industrial, que representou uma mudança irreversível nas formas de apropriação e transformação da natureza, como também na estruturação das relações sociais de produção, sendo, em virtude disso, considerada como um marco referencial na alteração das formas da cidade.

De forma que, este texto se propõe inicialmente a fazer uma breve exposição sobre as relações existentes entre o indivíduo, a cidade e a sociedade urbana; para então discutir os processos de formação, transformações e estrutura das cidades. Assim, será realizado um estudo sobre o desenvolvimento histórico das várias formas de cidade, desde o período antigo até os dias atuais, objetivando demonstrar que as mudanças econômicas decorrentes da modernidade globalizada sempre repercutiram no processo de desenvolvimento das cidades; continuando, realizaremos uma abordagem sobre o percurso histórico do surgimento das cidades brasileiras. Em seguida, será feita uma explanação sobre as várias correntes teóricas que se propõem a explicar a formação das cidades, enfatizando as tendências contemporâneas, especialmente a proposta progressiva.

Nesse contexto, ressalte-se que essa discussão pretende articular os campos jurídico, sociológico e urbanístico; sendo que, para isso, utilizaremos uma metodologia descritivoanalítica, por meio da realização de levantamentos bibliográficos e documentais, relacionando a temática do atual urbanismo, a partir da teorias das cidades, com os processos de formação, transformações e estrutura das cidades. De maneira que tais aspectos serão discutidos no âmbito das questões concernentes aos elementos indivíduo, natureza, cidade e sociedade urbana, sempre procurando um embasamento pro meio das legislações que tratam dos planejamentos urbanos das cidades. 


\section{INDIVÍDUO, CIDADE E SOCIEDADE URBANA}

Iniciaremos esse texto com uma antiga voz discursando sobre o poder e o fazer humanos, voz esta que já expressa a relevância que tem a presença do homem no ambiente natural e no meio urbano - o clássico canto do coral da Antígona, de Sófocles²:

Há muitas maravilhas, mas nenhuma é tão maravilhosa quanto o homem. Ele atravessa, ousado, o mar grisalho, impulsionado pelo vento sul tempestuoso, indiferente às vagas enormes na iminência de abismá-lo; e exaure a terra eterna, infatigável, deusa suprema, abrindo-a com o arado em sua ida e volta, ano após ano, auxiliado pela espécie equina.

Ele captura a grei das aves lépidas e as gerações dos animais selvagens: e prende a fauna dos profundos mares nas redes envolventes que produz, homem de engenho e arte inesgotáveis.

Com suas armadilhas ele prende a besta agreste nos caminhos íngremes; e doma o potro de abundante crina, pondo-Ihe na cerviz o mesmo jugo que amansa o fero touro das montanhas.

Soube aprender sozinho a usar a fala e o pensamento mais veloz que o vento e as leis que disciplinam as cidades, e a proteger-se das nevascas gélidas, duras de suportar a céu aberto, e das adversas chuvas fustigantes; ocorrem-lhe recursos para tudo e nada o surpreende sem amparo; somente contra a morte clamará em vão por um socorro, embora saiba fugir até de males intratáveis.

Sutil de certo modo na inventiva além do que seria de esperar, e na argúcia, que o desvia às vezes para a maldade, às vezes para o bem, se é reverente às leis de sua terra e segue sempre os rumos da justiça jurada pelos deuses ele eleva à máxima grandeza a sua pátria.

Nem pátria tem aquele que, ao contrário, adere temerariamente ao mal; jamais quem age assim seja acolhido em minha casa e pense igual a mim!

Como podemos observar, essa angustiante homenagem ao opressivo poder humano, descreve a sua invasão violenta na ordem cósmica, alcançando os diferentes domínios da natureza por intermédio de sua renitente esperteza; concomitantemente, exterioriza o fato de que, com a faculdade adquirida por meio do discurso, da reflexão e da sensibilidade social, ele constrói uma casa para sua própria existência - ou seja, o artefato da cidade. Assim sendo, o homem é o criador de sua existência como vida humana, amoldando as circunstâncias conforme sua vontade e necessidade, nunca se encontrando desorientado, exceto diante da morte. Em suma, a vida do homem desenvolveu-se entre o que permanecia e o que mudava: a

2 SÓFOCLES. A trilogia tebana. Édipo Rei, Édipo em Colono e Antígona. Trad. Mário da Gama Kury. 10.ed. Rio de Janeiro: Zahar, 2004. p. 215-216. (385, 390, 395, 400, 405, 410, 415, 420 e 425) 
natureza e as suas próprias obras, sendo a maior destas a cidade, a qual ele podia emprestar um certo grau de permanência por meios que inventava e aos quais se dispunha a obedecer. ${ }^{3}$ Ademais, ressalte-se que essa cidadela de sua própria criação, claramente diferente do resto das coisas e confiada aos seus cuidados, integra o domínio completo da responsabilidade humana. Em outras palavras, a natureza não era mais objeto desta ação do homem, pois ela cuidava de si mesma e, com a persuasão e a insistência necessárias, também tomava conta do ser humano; sendo que diante dela eram úteis a inteligência e a inventividade, não a ética. Mas, na cidade, ou seja, no artefato social onde homens lidam com homens, o poder intelectivo deve associar-se com a moralidade, pois esta é o sentido de sua existência.

Nesse contexto, é importante lembrar o pensamento de Marshall Berman ${ }^{4}$, quando propõe que nós e aqueles que virão depois de nós "continuarão lutando para fazer com que nos sintamos em casa neste mundo, mesmo que os lares que construímos, a rua moderna, o espírito moderno continue a desmanchar no ar". Além do mais, esse autor, citando Novalis destaca "[...] uma premência de estar em casa e nos assaltar em qualquer parte. Para onde, pois, estamos indo? Sempre para casa".

Feitas essas reflexões introdutórias, é possível afirmar que a cidade é a casa, o país, o mundo. De fato, a cidade é o espaço político de uma existência que se inicia, decorre e termina localmente; mas, é também a dimensão subjetiva, individual, pessoal. ${ }^{5}$ No próximo tópico, esclareceremos mais detalhadamente a concepção de cidade contemporânea, tornando-se evidente que esta não existiria como um corpus, independente dos indivíduos; até porque é inconcebível uma cidade sem seus habitantes.

Na constituição das sociedades antigas, várias famílias formavam a frátrea (entre os gregos) ou a cúria (entre os romanos), logo, muitas cúrias ou frátreas, agrupando-se, deram origem as tribos. Registre-se que tal constituição tinha particularidades específicas: o alimento preparado sobre o altar do deus protetor, dividido entre muitas pessoas, "estabelecia entre estas um vínculo indissolúvel, uma união santa só cessada com a morte. Na frátrea, como na família, havia um deus, um culto, um sacerdote, uma justiça, um governo. Era uma pequena sociedade modelada exatamente sobre a da família". 6 De modo que, unindo-se várias tribos, desta aliança surge a cidade; mas, "cidade e urbe não foram palavras sinônimas no mundo

\footnotetext{
3 JONAS, Hans. O princípio responsabilidade: ensaio de uma ética para a civilização tecnológica. Trad. Marijane Lisboa; Luiz Barros Montez. Rio de Janeiro: Contraponto, 2006. p. 32-33.

${ }^{4}$ BERMAN, Marshall. Tudo que é sólido desmancha no ar: a aventura da modernidade. Trad. Carlos Felipe Moisés; Ana Maria L. Ioriatti. São Paulo: Companhia das Letras, 1986. p. 394.

${ }^{5}$ GARCIA, Maria. A cidade e o Estado: políticas públicas e o espaço urbano. In: (Coord.). A cidade e seu Estatuto. São Paulo: Juarez de Oliveira, 2005. p. 27.

${ }^{6}$ COULANGES, Fustel de. A cidade antiga. Trad. Jean Melville. 2.ed. São Paulo: Martin Claret, 2007. p. 130 e 138.
} 
antigo. A cidade era associação religiosa e política das famílias e das tribos; a urbe, o lugar de reunião, o domicílio, e, sobretudo, o santuário dessa sociedade. [...] A cidade, entre os antigos, não se formava no decorrer do tempo, pelo lento crescimento do número de homens e das construções. Fundava-se a cidade de uma só vez, em um só dia" ${ }^{7}$, mediante todo um processo ritual próprio para o dia da fundação. Em resumo, essa foi a forma de nascimento do Estado entre os antigos, devendo-se esclarecer o seguinte aspecto: "se as primeiras cidades se formaram pela confederação de pequenas sociedades anteriormente constituídas, não quer isso dizer que tenham sido todas as cidades que nós conhecemos formadas da mesma maneira. Uma vez encontrada a organização municipal, não era exigido para cada nova cidade recomeçar o mesmo caminho, longo e dificultoso". ${ }^{8}$

Portanto, é visível a presença de todo um cerimonial que envolvia um ritual simbólico unindo o homem à cidade, na forma de famílias - contudo, isto representa igualmente o enfoque pessoal, social e patrimonial. Então, um conjunto de valores materiais e imateriais distinguem os habitantes de uma cidade em relação a outras, dotadas de nome próprio e origem, ligando assim o indivíduo à cidade.

Em um de seus diálogos, Aristóteles $^{10}$ já preocupado com a crise que poderia acometer a cidade, enfatizava os grandes cataclismas que periodicamente destroem a humanidade. Então, retratava as etapas que devem percorrer os sobreviventes de sua descendência para refazer a civilização: os que escaparam ao dilúvio de Deucalião tiveram inicialmente que redescobrir os meios elementares de subsistência e, depois, reencontrar as artes que embelezam a vida; num terceiro estágio, direcionavam seus olhares para a organização da polis, inventando as leis e todos os vínculos que reúnem as partes de uma cidade.

Na Grécia Antiga, a cidade é, sobretudo, a polis, a sociedade política, que foi tratada notadamente por Aristóteles $^{11}$, buscando os seus minuciosos aspectos, no sentido de estabelecer sua finalidade:

\footnotetext{
7 COULANGES, 2007, p. 145.

8 Ibid., p.144.

9 Nos dias atuais, palavras como indivíduo, sociedade, personalidade e coletividade, por serem armas ideológicas das lutas de poder de vários partidos e Estado, encontram-se impregnadas de um certo conteúdo emotivo, tornando assim dificultoso a delimitação exata do núcleo concreto dos desejos e temores dos que estão envolvidos nas relações. A palavra indivíduo, por exemplo, pode despertar sentimentos negativos em pessoas para quem a doutrina do individualismo é desagradável; em sentido contrário, essa mesma palavra pode está associada a um orgulho por sua posição independente na sociedade, podendo simbolizar aquilo que a pessoa isolada é capaz de realizar, independentemente de todas as demais e em concorrência com elas, por energia e mérito próprios. Cf. ELIAS, Norbert. A sociedade dos indivíduos. Trad. Vera Ribeira. Rio de Janeiro: Zahar, 1994. p. 74-75.

${ }^{10}$ Cf. FESTUGIÈRE, A. J. La révélation d'Hermès Trismégiste: le dieu cosmique. Paris: [s.n.], 1949. p.219.

${ }^{11}$ ARISTÓTELES. A política. Trad. Nestor Silveira Chaves. 2.ed. Bauru-SP: EDIPRO, 2009. 1252a 5.
} 
Sabemos que toda cidade é uma espécie de associação, e que toda associação se forma tendo por alvo algum bem; porque o homem só trabalha pelo que ele tem em conta de um bem. Todas as sociedades, pois, se propõem a qualquer bem - sobretudo a mais importante delas, pois que visa a um bem maior, envolvendo todas as demais: a cidade ou sociedade política.

Assim, Aristóteles $^{12}$, já tendo estabelecido a finalidade da cidade, em seguida, procura definir "[...] o que é uma cidade", sendo ela algo de complexo, assim como qualquer outro sistema composto de elementos ou de partes. Logo, é preciso, evidentemente, "procurar antes de tudo o que é um cidadão. Porque a cidade é uma multidão de cidadãos [...] - aqueles que podem ser juiz e magistrado [...]; ou, em outros termos, aquele que tem uma parte legal na autoridade deliberativa e na autoridade judiciária - eis o que chamamos cidadão da cidade assim constituída". Porém, restam ainda os não cidadãos, incluídos os escravos e estrangeiros; de maneira que, "[...] como se reconhecerá que a cidade é uma? Certamente não é pelas muralhas; [...]. Mas, desde que os homens habitem o mesmo lugar, será preciso dizer, já que não varie a espécie de seus habitantes, que a cidade é sempre a mesma".

Após essas considerações, surge o questionamento sobre quem são os habitantes da cidade, sendo a resposta mais óbvia: indivíduos, pessoas. Aliás, todas as problemáticas e complexidades da questão urbana convergem, especificamente, ao único elemento social, ou seja, o ser-homem. Quanto a este aspecto, Deleuze ${ }^{13}$ relata que, na obra de Michel Foucault, é possível observar um encadeamento entre os artigos sobre Nietzsche e Blanchot, na oportunidade em que é tratada a questão das forças componentes do homem, como podemos observar:

Ora, na Idade Clássica, todas as forças do homem são referidas a uma força de 'representação' que pretende extrair o que nele há de positivo, ou de elevável ao infinito: de tal forma que o conjunto das forças compõe. Deus, não o homem, e que o homem só pode aparecer entre ordens de infinito. [...] Para que o homem apareça como composto específico, é preciso que suas forças componentes entrem em relação com novas forças que se esquivem à da representação e, inclusive, a destituam. Essas novas forças são as da vida, do trabalho e da linguagem, visto que a vida descobre uma 'organização', o trabalho uma 'produção', a linguagem uma 'filiação' que os situa fora da representação. Essas forças obscuras da finitude não, a princípio, humanas, mas entram em relação com as do homem para reduzi-las à sua própria finitude e comunicar-Ihes uma história. [...] Mas, se imaginarmos uma terceira extração, ou lance, as forças do homem estarão em relação com outras forças ainda, de

\footnotetext{
12 ARISTÓTELES, 2009, 1274b 35, 40; 1275a 5, 25; 1275b 20, 35; e 1276a 25, 35.

13 DELEUZE, Gilles. Foucault. Trad. Cláudia Sant'Anna Martins. São Paulo: Brasiliense, 2005. p. 93-96.
} 
maneira a compor uma outra coisa ainda, que não será mais Deus, nem o homem: dir-se-ia que a morte do homem se concatena com a de Deus, para formar novos compostos. [...] Não se diz, correntemente, que as forças do homem já entraram em relação com outras forças, as da informação, que compõem com elas uma coisa diferente do homem, sistemas indivisíveis 'homem-máquina', com máquinas de terceira geração? Uma união com o silício, mais do que com o carbono?

Como é possível perceber, na formação histórica das forças do ser-homem, não se trata mais das consequências advindas dos problemas de convivência e conflitos entre o cidadão e o estrangeiro, e sim das análises da representação e dos sentidos, chegando ao plano da forma futurista, por meio, da robótica, da tecnologia ciborguiana, da bioética etc. Aliás, a discussão sobre o cidadão e o estrangeiro foi tratada detalhadamente por Coulanges ${ }^{14}$, distinguindo 0 cidadão como aquele que participava do culto da cidade, em suas várias formas, provindo assim todos os seus direitos civis e políticos; por conseguinte, tratava-se de uma vinculação inerente à própria existência da polis. Já o estrangeiro, pelo contrário, era aquele que não tinha acesso ao culto, não tendo então a proteção dos deuses, nem tampouco o direito de invocá-los; com efeito, esses deuses das cidades apenas recebem orações e oferendas do cidadão, repelindo todo homem estrangeiro, sendo, inclusive, proibida a entrada destes nos templos.

Em conformidade com Coulanges ${ }^{15}$, toda a resistência da Cidade Antiga parecia que tinha o "propósito de estabelecer um sistema vexatório contra o estrangeiro. Mas, não era nada disso, pelo contrário, Atenas e Roma recebiam o estrangeiro com agrado e até protegiam por razões comerciais ou políticas"; sendo que, tal benevolência e interesses não podiam abolir as velhas leis estabelecidas pela religião, não permitindo ao estrangeiro torna-se proprietário, pois este não possuía parte do solo religioso da cidade. Assim, para que o estrangeiro pudesse ter algum valor aos olhos da lei (comercializar, contratar, usufruir dos seus bens com segurança, enfim, para a justiça da cidade o defender eficazmente), tornava-se indispensável a sua submissão como cliente de qualquer cidadão. Dessa forma, tais cidades exigiam que todo estrangeiro adotasse um patrono, para que fizesse parte da clientela, mas sempre na dependência de um cidadão, ficando ele vinculado à cidade por meio dessa relação intermediária, podendo, inclusive, participar de alguns benefícios do direito civil e adquirir proteção das leis.

De modo que, verifica-se um profundo vínculo entre o cidadão e a cidade, que é fortalecido pela necessária intermediação do cidadão nas possíveis relações do estrangeiro com a polis. Saliente-se que, muito embora esse vínculo tenha ocorrido há séculos passados,

\footnotetext{
${ }^{14}$ COULANGES, 2007, p. 213 et seq.

15 Ibid., p. 206, 213 e 238.
} 
podemos ainda vislumbrar a situação do "forasteiro" ${ }^{16}$, apesar da condição social, do ponto de vista político e jurídico, não ser, evidentemente, a mesma.

Com relação à perspectiva da sociedade urbana, em geral esta é designada como qualquer cidade: a grega, a oriental ou medieval, a comercial ou industrial, a pequena, média ou megalópole. Portanto, além desta situação de entropia, também não é tratada a questão das relações sociais (de produção) inerentes a cada tipo urbano. Mas, neste texto, nos limitaremos ao entendimento da sociedade urbana como aquela que nasce do processo de industrialização, que dominou e absorveu a produção agrícola; de maneira que, tal sociedade é concebida ao final de um processo no qual são extintas as antigas formas urbanas.

As ciências sociais especializadas vêm propondo inúmeras denominações ${ }^{17}$ para caracterizar a sociedade atual, levando em consideração as realidades, tendências e atualidades. Logo, pode se falar de sociedade industrial, sociedade pós-industrial, sociedade do consumo, sociedade do espetáculo etc. Assim, cada uma dessas denominações implica em uma proposta conceitual, como, por exemplo, sociedade pós-industrial é aquela que nasce da industrialização e a sucede; já a sociedade urbana designa a tendência e a orientação, não tirando, contudo, outras caracterizações. Nesse contexto, Lefebvre ${ }^{18}$ desenvolve um eixo que vai da ausência da urbanização (a "pura natureza", a terra entregue aos "elementos") à culminação do processo, sendo esse traçado ao mesmo tempo espacial e temporal: no primeiro caso porque se estende no espaço que ele modifica; e no segundo, devido ao fato de que ele se desenvolve no tempo, depois da prática e da história.

$\mathrm{Na}$ trajetória percorrida pelo fenômeno urbano, inicialmente são observadas populações destacadas pela etnologia e antropologia, tendo, em torno deste marco inicial, os primeiros grupos humanos (coletores, pescadores, caçadores, talvez pastores) que exploraram,

\footnotetext{
16 Sobre esta perspectiva, no final do século passado Norbert Elias desenvolveu um trabalho etnográfico utilizando indicadores sociológicos correntes (renda, educação, tipo de ocupação etc.) em Winston Parva (cidade fictícia do interior da Inglaterra), que muito embora fosse uma comunidade relativamente homogênea, não era esta a percepção daqueles que ali moravam. Para eles, o povoado estava claramente dividido entre um grupo que se percebia, além de ser reconhecido, establishment local, e um outro conjunto de indivíduo e famílias outsiders: os primeiros fundavam sua distinção e seu poder em um princípio de antiguidade, pois moravam em Winston Parva muito antes que os outros, estereotipando os valores da tradição e da boa sociedade; enquanto que os outros viviam estigmatizados por todos os atributos associados à anomia, como delinquência, violência e desintegração. Em suma, superioridade social e moral, auto-percepção e reconhecimento, pertencimento e exclusão são os elementos dessa dimensão de vida social que o par estabelecidos-outsiders ilumina exemplarmente. Cf. ELIAS, Norbert. Estalecidos e outsiders: sociologia das relações de poder a partir de uma pequena comunidade. Trad. Vera Ribeiro. Rio de Janeiro: Zahar, 2000.

17 Cf. KUMAR, Krishan. Da sociedade pós-industrial à pós-moderna: novas teorias sobre o mundo contemporâneo. Trad. Ruy Jungmann. Rio de Janeiro: Zahar, 1997; BAUDRILLARD, Jean. A sociedade de consumo. Trad. Artur Morão. Lisboa: Edições 70, 1970; COELHO, Claudio Novaes Pinto; CASTRO, Valdir José de. (Orgs.). Comunicação e sociedade do espetáculo. São Paulo: Paulus, 2006.

18 LEFEBVRE, Henri. A revolução urbana. Trad. Sérgio Martins. Belo Horizonte: UFMG, 2008. p.18.
} 
marcaram e nomearam o espaço. Então, a topologia espacial, que posteriormente os camponeses aperfeiçoaram, revela que em todos os lugares onde a história aparece, a cidade acompanhou de perto a aldeia. De forma que surge uma ideologia na qual o campo cultivado, a aldeia e a civilização camponesa teriam gradativamente produzido a realidade urbana, sendo que tal concepção generaliza o que se passou na Europa por ocasião da decomposição do Império Romano e da reconstituição das cidades na Idade Média. Por sua vez, é igualmente pertinente a ideia de que a agricultura somente superou a coleta a partir do impulso desencadeado pelos centros urbanos, geralmente ocupados por conquistadores hábeis, que se tornaram protetores, exploradores e opressores, ou seja, administradores, fundadores de um Estado ou mesmo de um esboço de Estado. Em suma, a cidade política acompanha o estabelecimento de uma vida social organizada, da agricultura e da aldeia. ${ }^{19}$

Na perspectiva do eixo espaço-temporal proposto por Lefebvre, a cidade política era povoada por sacerdotes, guerreiros, príncipes, nobres, chefes militares, administradores e escribas. Todavia, ela também integrava os artesanatos e as trocas, tendo em vista que administra, protege e explora um vasto território dotado de atividades agrícolas (drenagem, irrigação, construção de diques etc.), controlando, assim, um determinado número de aldeias, onde um monarca é o titular da propriedade do solo e os camponeses conservam a posse mediante pagamento de tributos.

No final da Idade Média, a mercadoria, o mercado e os mercadores penetram nas cidades do ocidente europeu, podendo se afirmar que outrora os mercadores nômades, guerreiros e saqueadores, optaram pelas ruínas das antigas cidades romanas para lutarem contra os senhores territoriais. Desse modo, uma nova cidade política teria servido de quadro à ação que iria transformá-la e, no decorrer dessa luta (de classes) contra os senhores territoriais, a praça do mercado torna-se central, ocupando o espaço da reunião (a ágora, o fórum); sendo que em torno do mercado localizam-se a igreja e a prefeitura, com sua torre e seu campanário como símbolo de liberdade. Neste momento, é importante ressaltar que a arquitetura traduz uma nova concepção de cidade, pois o espaço urbano torna-se o lugar do encontro das coisas e das pessoas, da troca. Já no século XIV, acredita-se na possibilidade do estabelecimento de um mercado e na construção de lojas, pórticos e galerias ao redor da praça central, para que os mercadores e compradores comercializem; por conseguinte, os senhores e os burgueses edificam a denominada cidade mercantil, que tem seu lugar logo após a cidade política; saliente-se que, nesse período, na Europa Ocidental, a troca comercial torna-se função urbana,

${ }^{19}$ LEFEBVRE, 2008, p.19. 
surgindo, então, novas formas arquiteturais e urbanísticas, decorrentes de uma outra estrutura de espaço urbano.

Então, nessa realidade conjuntural, revelada pela relação entre a cidade e o campo, ainda se reconhecia a prioridade deste; ou seja, à riqueza imobiliária, aos produtos do solo, às pessoas estabelecidas territorialmente etc., eram aspectos inerentes ao campo. Mas, em um dado momento, essas relações foram invertidas e, desde então, a cidade não aparece mais como uma ilha urbana em um oceano camponês, visto que ela entra na consciência e no conhecimento como um dos termos, igual ao outro, da oposição cidade-campo. Em outras palavras, o campo passa a ser não mais que a circunvizinhança da cidade, seu horizonte, seu limite; com as pessoas da aldeia deixando de trabalhar para os senhores territoriais e passando a produzir para a cidade, para o mercado urbano, pois eles sabem que os mercadores os exploram, encontrando no mercado o caminho da liberdade. ${ }^{20}$ Portanto, após esse fato crucial, os indivíduos que refletem não mais se veem na natureza, haja vista que entre a consciência coletiva dos mesmos e o mundo instala-se uma mediação essencial, traduzida pela realidade urbana.

Com a destruição de Atenas e de Roma, a ideia do racionalismo acompanha a inversão que substitui a primazia camponesa pela prioridade urbana, sendo nesse período que nasce a imagem da cidade, que já detinha a escrita e possuía seus segredos e poderes, bem como já opunha a urbanidade à rusticidade. De fato, a partir de um determinado momento a cidade passa a ter sua escrita específica, sob a forma da planimetria. Com efeito, nos séculos XVI e XVII, quando acontece essa inversão da ordem das coisas, aparecem, na Europa, os primeiros planos de cidades, mesmo que sem uma abstração adequada, com projeções do espaço urbano em meio a coordenadas geométricas; em síntese, era uma associação entre a visão e a concepção, obras de artes e de ciência, com os planos mostrando a cidade a partir do alto e de longe, descrevendo-a geometricamente.

De maneira que, essa inversão de sentido não pode ser dissociada do crescimento do capital comercial e da existência do mercado, pois é a cidade comercial que está sendo implantada na cidade política; sendo que àquela vai prosseguindo com sua marcha ascendente, tendo em vista que convive com emergência do capital industrial e, consequentemente, com o surgimento da cidade industrial. Realmente, nessa perspectiva a indústria estaria ligada a nãocidade, pois, sabe-se que, de início, a industria se implanta próxima às fontes de energia (carvão, água etc.), das matérias primas (metais, têxteis, entre outras) e das reservas de mão-

${ }^{20}$ LEFEBVRE, 2008, p.21-22. 
de-obra. ${ }^{21}$ Então, se a indústria se aproxima das cidades apenas para reunir os capitais, os capitalistas, os mercados e uma abundante mão-de-obra em geral mantida a baixo preço, ela pode se implantar em qualquer lugar, visto que cedo ou tarde alcançará as cidades preexistentes, ou mesmo constituirá novas cidades.

No decorrer desse processo social e econômico dinâmico, a realidade urbana perde os traços que a ética anterior lhe conferia: totalidade orgânica, sentido de pertencimento, espaço demarcado e dominado pelos monumentos etc. Sem dúvida, surge um novo povoamento com os signos do urbano na dissolução da urbanidade, exteriorizados pela estipulação, ordem repressiva e códigos limitados de circulação e referência. Em consequência disso, a cidade industrial precede e anuncia uma zona crítica, advinda do crescimento da produção industrial, superpondo-se ao das trocas comerciais, que vai desde o escambo ao mercado mundial, da troca simples entre dois indivíduos até a troca de produtos, das obras, dos pensamentos dos seres humanos. Em suma, a compra e venda, a mercadoria e o mercado, o dinheiro e o capital, parecem superar todos os obstáculos; mas, no âmbito dessa generalização, surge a problemática urbana impondo-se em escala mundial.

Enfim, após essa explanação, compreendemos que a discussão sobre a sociedade urbana e as modalidades de urbanização depende das características da sociedade considerada no curso do processo de industrialização (capitalista ou socialista, em crescimento econômico ou já altamente tecnológico). Então, as diferentes formas de entrada da sociedade urbana, com suas implicações e consequências, são partes integrantes da problemática inerente ao fenômeno urbano, sendo este termo, no entendimento de uma determinada corrente de autores ${ }^{22}$, preferível à palavra "cidade", que para eles parece designar um objeto definido e definitivo, enquanto que a abordagem teórica solicita inicialmente uma crítica desse objeto, exigindo uma noção mais complexa. Por conseguinte, nesta concepção não há uma ciência da cidade (sociologia urbana, economia urbana etc.), mas um conhecimento em permanente formação do processo global.

Finalizamos este tópico, salientando que acompanharemos a linha de pensamento germânico, que adota discussões a partir da noção de cidade, com suas teorias próprias sobre a formação das civilizações humanas e de suas cidades. Assim, passaremos a desenvolver uma análise sobre as noções conceituais relacionadas com a cidade, para que seja possível uma adequada compreensão quanto a formação, transformações e estruturação das cidades.

\footnotetext{
21 LEFEBVRE, 2008, p.24.

${ }^{22}$ Cf. FREITAG, Barbara. Teorias da cidade. Campinas-SP: Papirus, 2006. p.17-18.
} 


\section{CIDADES: FORMAÇÃO, TRANSFORMAÇÕES E ESTRUTURAÇÃO}

Na modernidade contemporânea, a cidade vem sendo analisada a partir de seus processos de formação e transformação, bem como de sua estruturação interna. Mas, para tanto, é necessário uma abordagem preliminar sobre a complexidade que orienta suas dinâmicas e seus antagonismos; até porque a cidade é, por excelência, o lugar de concentração da vida social, econômica, política e cultural.

Assim, para definir o que seja uma cidade, é imprescindível a consideração dos vários elementos que se relacionam historicamente em diferentes territórios geográficos. Além do mais, na conceituação da cidade, devem ser discutidas as múltiplas implicações inerentes ao Processo de Urbanização, pois é a partir dessa visão pluridimensional que poderemos compreender como as concepções de cidade são construídas, bem como em que medida são dimensões adequadas para explicar o mundo urbano atual.

Os processos e práticas sociais humanas são partes integrantes de um conjunto de determinações cujas imbricações constituem a base das relações entre a cidade e o meio urbano. Sem dúvida, a cidade não se resume ao conjunto de edifícios com diversificadas formas de uso ou mesmo ao arruamento, por onde circulam pessoas e veículos, nem tampouco ao território ocupado, distintamente, pelos atores sociais em suas atividades econômicas e culturais. Realmente, a cidade é bem mais de que cada uma dessas dimensões, pois ela vai além da simples articulação entre elas. Logo, para um adequado entendimento da cidade, é necessário fazer uma regressão no tempo, em busca de sua gênese, como também proceder a um estudo das diferentes manifestações urbanas no mundo presente. Assim, iniciaremos a discussão sobre o que é cidade, interpretando algumas definições propostas por autores de variadas áreas de conhecimento científico, as quais, conjuntamente, acreditamos que são capazes de estruturar o conceito de cidade.

Para Beaujeau-Garnier23, a cidade deve ser entendida como "multiforme por sua situação, tamanho, arquitetura, organização interna, papel na vida regional ou nacional"; portanto, na concepção desta autora, a cidade deve ser estudada de variadas formas: "[...] por corresponder a um modo particular de ocupação do solo; por reunir em um espaço mais ou menos vasto, mas, no entanto, muito denso, grupos de indivíduos que vivem e produzem; a cidade pode ser dinâmica e próspera ou degradada e quase moribunda [...]". De fato, a cidade é o aspecto fundamental da organização do espaço. Continuando, esclarece Beaujeau-Garnier ${ }^{24}$ que "[...] a cidade existe concretamente; é o quadro do exercício de uma função social (cultura,

\footnotetext{
${ }^{23}$ BEAUJEAU-GARNIER, Jacqueline. Geografia urbana. Lisboa: Calouste Gulbenkian, 1980. p.16.

24 Ibid., p.22.
} 
valor, proteção do indivíduo); é o elemento funcional de um sistema econômico; [...] é uma unidade definida pelo cotidiano do mercado de trabalho". Segundo esta autora, é necessário entender a cidade como uma concentração de pessoas, de necessidades e de possibilidades de toda natureza, que reune um grande potencial de organização e transformação; consequentemente, ela deve ser compreendida, ao mesmo tempo, como "sujeito e objeto". Na condição de objeto, ela existe materialmente, com todos os seus elementos que exercem atividades de produção e de consumo, utilizando seus variados equipamentos; já como sujeito, exerce influência sobre seus habitantes, em termos de atitudes e impulsos. Então, se o homem utiliza e molda a cidade, logo, a recíproca é verdadeira.

Diante o que foi exposto, é possível afirmar que a cidade exterioriza os interesses e as ações da sociedade e, concomitantemente, oferece condições para que tais práticas se realizem, contribuindo assim, para a determinação do próprio movimento advindo dessas ações.

Outrossim, é pertinente destacar o fato de que a cidade comporta atividades caracteristicamente urbanas, sendo que isso não implica que apenas em seus espaços sejam realizados o que é "urbano" no mundo contemporâneo, nem tampouco que existam limites determinados entre a cidade e o campo. Pelo contrário, atualmente, as paisagens da cidade e do campo apresentam-se imbricadas e difusas, como superposições de difícil explicação apenas pela observação. Com efeito, só é possível ter uma avaliação do que pode ser urbano ou rural com base na análise das dinâmicas e das práticas socioespaciais; mas, registre-se que tais dinâmicas só poderão ser apreendidas pela localização das infraestruturas e das atividades nos espaços, como os sistemas viários, as fábricas, os equipamentos comerciais e de serviços residenciais, à disposição de pequenas propriedades que delimitam os cinturões verdes. Em síntese, todas essas localizações se articulam entre si por meio de transportes, telecomunicações, trajetos realizados pelos pedestres etc. De modo que, observa-se que existem várias maneiras de apropriação dos espaços para diferentes atividades e usos pelos sujeitos sociais, desde o plano individual até os grandes conglomerados urbanos, incluindo a divisão social e territorial do trabalho pela qual é possível uma compreensão mais visível da cidade e do campo, bem como da manifestação do que é urbano ou rural.

Do ponto de vista legal, é possível a distinção entre a cidade e o campo por intermédio do mapeamento inerente ao Imposto Predial e Territorial Urbano (IPTU), que é circunscrito no âmbito da cidade propriamente dita. Todavia, não podemos compreender a cidade e o campo apenas pelo ponto de vista legal, pois, muito embora não seja comum, ainda são encontradas nas cidades de variados tamanhos atividades agrícolas em áreas loteadas, revestindo a 
superfície de lotes tidos como urbanos. Além disso, existem outros indicadores que igualmente precisam ser levados em consideração para um adequado entendimento sobre a cidade, tais como a natureza e a densidade das infraestruturas (abastecimento de água regular, vias com e sem pavimentação, redes de iluminação, telefonia e coleta de esgoto etc.), os equipamentos de consumo coletivo (escolas, hospitais, parques, praças, entre outros), os serviços urbanos (coleta de lixo, segurança, limpeza de vias, etc.).

No contexto brasileiro, o que é considerado uma cidade é a sede do município, em uma evidente adoção do critério político-administrativo, estando tal definição presente no DecretoLei no 311, de 1938, aprovado durante o Estado Novo, no governo de Getúlio Vargas. Ressaltese que esse dispositivo ainda hoje vigora como base para levantamentos estatísticos, ações da administração pública, buscas de informações geográficas etc. Por essa razão, como há aproximadamente 6.000 municípios no território brasileiro, esse seria o número das cidades existentes no país, nas quais vivem quase $80 \%$ da população. ${ }^{25}$

No ano de 2001, em cumprimento à Constituição Federal Brasileira de 1988, foi aprovado o Estatuto da Cidade (Lei no 10.257/2001), que não faz, especificamente, a definição do que seja cidade, remetendo às Câmaras Municipais o estabelecimento das delimitações territoriais de suas cidades, objetivando a estruturação das bases para os Censos Demográficos realizados a cada 10 anos. Cumpre salientar, que há outros critérios para a definição do que seja cidade, por exemplo, no Reino Unido e na África do Sul, são consideradas cidades aqueles núcleos definidos administrativamente, que nos termos da classificação brasileira seriam chamados de municípios. Por sua vez, há países que adotam o critério populacional (número de habitantes) para estabelecer o que é cidade; então, uma aglomeração com 250 habitantes já é cidade na Dinamarca, com 2.000 habitantes, na França, enquanto que na Holanda, só é considerada cidade uma aglomeração com, no mínimo, 20.000 habitantes.

Em síntese, observamos que há uma grande diversidade de critérios para se definir o que é cidade, principalmente se os indicadores estabelecidos forem apenas o populacional e o administrativo; sendo, nesta hipótese, necessário inserir outros indicadores que auxiliem na definição da cidade e, especialmente, do que é urbano. Mas, mesmo que sejam adotados outros critérios, eles sempre tendem a se basearem nos dados demográficos e/ou administrativos. Logo, compreendemos que para um adequado entendimento do fenômeno urbano (seja para definir cidade ou o que é o aspecto urbano), é preciso trabalhar com os

${ }^{25}$ SPOSITO, Eliseu Savério. Redes e cidades. São Paulo: UNESP, 2008. p.16. 
elementos que traduzem a realidade material da sociedade, como, por exemplo, a divisão de trabalho a partir de uma perspectiva de processos de produção, circulação, troca e consumo. ${ }^{26}$

Nessa conjuntura, é pertinente destacar que a cidade é um território que depende de realidades e mecanismos diferentes, exteriorizados pelas rupturas relacionadas não apenas à dimensão ou estatuto, como aquelas existentes entre o que é urbano e o que é rural. Indiscutivelmente, a definição de cidade é bem mais ampla, podendo ser complementada por aspectos particulares, envolvendo "[...] necessidades cotidianas, fontes de alimentação e de rendas, serviços", entre outros, que são direcionados ao exterior. ${ }^{27}$

Com relação às transformações que vem ocorrendo no âmbito das cidades, delimitaremos o cenário epistemológico a partir da época dos grandes descobrimentos, embora no decorrer deste texto possa haver informações de quando as cidades começaram a se estabelecer como lugar diferenciado de produção de ideias e objetos. Em resumo, procuraremos contextualizar a cidade produzida e transformada pelas relações capitalistas de produção por ocasião da primeira Revolução Industrial.

Na compreensão de Benevolo ${ }^{28}$, a cidade diferencia-se da aldeia pela sua faculdade de ser mais dinâmica e se transformar mais rapidamente; além disso, ela tem sua própria dimensão temporal, que é diversa da aldeia, definido pelas atividades do campo. Assim, a cidade é o lugar do poder, sendo sua origem justificada pela existência de um excedente agrícola; ou seja, enquanto seus habitantes estão mais direcionados para práticas artesanais e o exercício do poder, os camponeses têm de produzir alimentos e matérias primas para si como também para as vilas e cidades. Continuando, esse autor assevera que as sociedades neolíticas já "conheciam os cereais cultiváveis, o trabalho dos metais, a roda, o carro puxado pelos bois, o burro de carga, as embarcações a remo ou à vela" e, devido a isso, naquela época, começou "a espiral da nova economia: o aumento da produção agrícola, a concentração do excedente nas cidades e ainda a elevação de população e de produtos garantidos pelo domínio técnico e militar da cidade sobre o campo".

Ao discorrer sobre os aspectos históricos da cidade antiga, Coulanges ${ }^{29}$ afirma que foi por temor aos deuses que os romanos passaram a realizar rituais e cultos a terra, porque a religião deles era de caráter notadamente político. Nesse sentido, enfatiza esse autor que para a fundação de uma cidade:

\footnotetext{
${ }^{26}$ Cf. MARX, Karl. Para a crítica da economia política. In: Manuscritos econômicos-filosóficos e outros textos escolhidos. Trad. José Carlos Bruni; et al. 4.ed. São Paulo: Nova Cultural, 1987. p. 3 et seq.

27 RONCAYOLO, M. La ville et ses territoires. Paris: Gallimard, 1990. p.19.

${ }^{28}$ BENOVOLO, Leonardo. História da cidade. São Paulo: Perspectiva, 1983. p.26.

${ }^{29}$ COULANGES, 2007. p. 146-147.
} 
O primeiro cuidado do fundador é a escolha do local para a nova cidade. Mas, essa escolha, coisa grave e da qual se crê depender o destino do povo, é sempre entregue à decisão dos deuses. Se Rômulo fosse grego, teria consultado o Oráculo de Delfos; [...] Chegado o dia da fundação, Rômulo oferece, antes de mais nada, um sacrifício. Os companheiros estão dispostos à sua volta, acendem o fogo de ramos e, um por vez, saltam através da chama. [...] Depois de essa cerimônia preliminar ter preparado o povo para o ato solene da fundação, Rômulo cava um pequeno fosso de forma circular. Lança neste o torrão por ele trazido da urbe de Alba. Depois, cada um dos seus companheiros lança, imitando Rômulo, um pouco de terra que também trazia do país de onde viera. [...] Lá estava o seu lar; lá seus pais tinham vivido e estavam enterrados. A religião proibia deixar a terra onde se tinha fixado o lar e onde os antepassados divinos repousavam. Era preciso, pois, para se libertar de toda a impiedade, que cada homem usasse de uma ficção e levasse consigo, simbolizado pelo torrão, o solo sagrado onde os seus antepassados estavam sepultados. [...] O homem não podia se mudar sem levar consigo o seu solo e seus ancestrais. Era preciso observar esse rito para, ao mostrar o novo lugar que havia adotado poder dizer: esta é ainda a terra de meus pais.

De acordo com Coulanges ${ }^{30}$, tanto em Roma como na Grécia Antiga, o medo aos deuses era patente, pois "os gregos, assim como os italianos, acreditavam que a localização de qualquer urbe devesse ser escolhida e revelada pela divindade [...]; não há lugar na urbe que não esteja impregnado de religião e ocupado por alguma divindade. [...] Algo de sagrado e de divino se ligava naturalmente a essas urbes que os deuses haviam levantado". Dessa maneira, conclui esse autor que a cidade, notadamente na Grécia, foi fundada como se fosse uma religião; logo, em uma sociedade que se fundamentava nessas razões, o cidadão ficava submetido, em tudo e sem reservas, à cidade, sem liberdade e à disposição do Estado.

Na diferenciação entre a cidade e o campo, que se exterioriza com a divisão do trabalho e consequente emergência das classes sociais antagônicas, também está presente o exercício da religião e da política por parte dos governantes, sendo isso possível por meio da organização de territórios onde o poder se instala e expande seu alcance para outras cidades e para o campo. De um modo geral, isso acontece desde a Antiguidade, passando pela Idade Média, sendo que nesta época o processo foi diferente, pois nos territórios da atual Europa não era comum uma cidade dominar a outra, haja vista que não havia impérios ou Estados fortes, chegando aos tempos do Renascimento, com as formas da cidade se alterando lentamente. Com a Revolução Industrial houve uma mudança irreversível nas formas de apropriação e

30 COULANGES, 2007, p. 150 e 153-154. 
transformação da natureza, bem como na organização das relações sociais de produção, sendo, devido a isso, considerada como um marco significativo na alteração das formas da cidade.

Com efeito, a cidade, que tinha características do que chamamos de valor de uso, com a consolidação do capitalismo, passa a influenciar tudo o que nela se constrói (arruamentos, edificações, praças, componentes de infraestrutura etc.); por conseguinte, ela passa a ser dotada, além do valor de uso, do valor de troca ${ }^{31}$ e da inseparabilidade, destas duas dimensões das mercadorias. Então, é necessário entender as formas de uso do solo na cidade por intermédio da luta entre proprietários e não-proprietários de imóveis, como também pela diferença entre o direito à propriedade e o direito à apropriação da terra.

Ao considerar a estruturação interna da cidade, Corrêa $^{32}$ desenvolve uma ampla abordagem sobre o espaço urbano, enfatizando que a cidade, "fragmentada, articulada, reflexo e condicionante social, é também o lugar onde as diversas classes sociais vivem e se reproduzem; [...] um conjunto de símbolos e campo de lutas". Continuando, esse autor ressalta que o espaço urbano "é um produto social, resultado de ações acumuladas através do tempo e engendradas por agentes que produzem e consomem o espaço". Assim, Corrêa $a^{33}$ elenca os diferentes agentes produtores do espaço urbano do seguinte modo:

Os proprietários dos meios de produção - personificados pelos donos de grandes indústrias e empresas comerciais que, pela conformação de suas atividades, estabelecem as dimensões de sua ocupação na cidade e sua grande capacidade de consumo do espaço urbano, por exemplo, ao localizarem suas empresas, ao longo das vias férreas, próximas aos portos ou em locais que oferecem amplas possibilidades de acesso; os proprietários fundiários, cujo objetivo principal é extrair, de forma ampliada, a renda fundiária de suas propriedades, tanto pelo uso residencial quanto pelo uso comercial, buscando mais o valor de troca do solo que o valor de uso; os promotores imobiliários, que são responsáveis por operações (incorporação, financiamento, estudo técnico, construção e comercialização) que facilitam a compra e a venda de fragmentos da cidade; o Estado, que tem uma atuação complexa e variável, tanto no tempo como no espaço, refletindo a dinâmica da sociedade da qual é parte constituinte; e os grupos sociais excluídos, que são aqueles que demandam, sobretudo, moradia nas cidades. (grifos nossos).

${ }^{31} \mathrm{O}$ valor de troca significa "a faculdade que a posse de determinado objeto oferece de comprar com ele outras mercadorias". Cf. SANDRONI, P. Dicionário de economia. São Paulo: Best Seller, 1989. p.322. Sobre valor de uso e valor de troca, ver também o Primeiro e Segundo Capítulos do trabalho de Marx, do Livro I, Do capital. MARX, 1987, p. 35 et seq. e 63 et seq.

${ }^{32}$ CORRÊA, Roberto Lobato. O espaço urbano. São Paulo: Ática, 1989. p. 9.

${ }^{33}$ Ibid., p.11. 
Como podemos ver, os proprietários dos meios de produção são responsáveis pela comercialização das mercadorias produzidas, já os proprietários de terrenos ou edificações destinados à venda ou ao aluguel visam à obtenção da renda fundiária, que se refere à capacidade que as pessoas têm de se apropriar, sob a forma de dinheiro, de tudo o que é produzido. Todavia, nessas relações estão presentes os conflitos e interesses, notadamente por parte dos proprietários fundiários que, a partir da lógica do sistema capitalista, buscam benefícios estatais em terrenos e edificações, transformando a terra rural em terra urbana, induzindo o crescimento demográfico da cidade, bem como orientando a sua dimensão territorial. De fato, tais proprietários interagem pressionando o poder público para que a infraestrutura seja instalada, o que facilita suas estratégias de definição de preços de venda do terreno ou da habitação, viabilizando então a obtenção do maior lucro possível. Registre-se que a instalação da infraestrutura e a utilização das denominadas "externalidades" (localização com vista para o mar, proximidade de áreas verdes, posição em relação ao relevo etc.), são aspectos importantes para as ações desses agentes. ${ }^{34}$

No que se refere à ação do Estado, ela é "marcada pelos conflitos de interesses dos diferentes membros da sociedade de classes, bem como pelas alianças entre eles", tornando viável a existência simultânea de objetivos distintos de vários agentes produtores e consumidores do espaço urbano. Quanto aos grupos sociais excluídos, é um fato público e notório que o acesso à moradia ocorre de forma seletiva devido às próprias condições da conjuntura capitalista, sendo a casa, em grande parte, produzida pelo sistema de autoconstrução em loteamentos periféricos em relação à cidade mais densamente ocupada ou até mesmo em loteamentos clandestinos, localizados nos subúrbios, em áreas públicas ou de proteção ambiental. ${ }^{35}$ Mas, quando isso acontece em áreas consideradas mais centrais, o surgimento das favelas é uma realidade concreta, principalmente em terrenos públicos, encostas íngremes ou áreas alagadiças. De forma que esses grupos sociais sempre convivem com a contradição de morar na cidade e lutar pelo direito de acesso a ela.

Nesse sentido, é pertinente destacar o pensamento de Roncayolo ${ }^{36}$, quando este autor esclarece que para se compreender as desigualdades da cidade, é necessário igualmente observar o papel dos agentes produtores do espaço nela construído. Além do mais, é possível acrescentar outras características para um adequado entendimento do crescimento na cidade, que além das determinações históricas, comporta também os crescimentos populacional, horizontal e vertical. O primeiro deles é o número de habitantes ou população de uma cidade,

34 CORRÊA, 1989, p. 11-13, 19 e 24.

35 Ibid., p.29-30.

36 RONCAYOLO, 1990, p.127-128. 
que pode ser subdividido em faixas etárias, profissões, renda, índice de natalidade e mortalidade etc. Já o crescimento horizontal é definido pelo perímetro da cidade com sua planta urbana, que vai se desdobrando com novos loteamentos ou ações que resultam na incorporação da terra rural à sua área. Saliente-se que o crescimento vertical tem suas estratégias propostas pelos agentes para propiciar a ampliação de forma bastante semelhante às verificadas na hipótese do horizontal; visto que a incorporação de novos lotes para a construção de edifícios residenciais ou de serviços é uma constante em cidades grandes ou mesmo de médio porte.

De um modo geral, observamos que na época atual, a análise das cidades vem se tornando cada vez mais complexa, haja vista o entrelaçamento com outras temáticas como sendo parte do estudo urbano, como, por exemplo, questões de invasões de áreas protegidas por lei, loteamentos clandestinos, destino dos resíduos sólidos, déficit habitacional, acesso às novas tecnologias, entre outras. Assim sendo, para uma compreensão concatenada sobre o desenvolvimento urbano das cidades, passaremos a fazer uma retrospectiva histórica com relação ao percurso das cidades antigas até as cidades dos dias atuais.

\section{DAS CIDADES ANTIGAS ÀS CIDADES CONTEMPORÂNEAS}

Inicialmente, é pertinente um esclarecimento sobre a noção de polis, que na compreensão de Bonini ${ }^{37}$ é "uma cidade autônoma e soberana, cujo quadro institucional é caracterizado por uma ou várias magistraturas, por um conselho e por uma assembleia de cidadãos (politai)". De modo que, trata-se do resultado de um processo de interpretação histórica diversificada, pois, falando da polis grega, é possível fazer a associação com os regimes oligárquicos (característicos dos séculos VIII-VI, e igualmente encontrados nos séculos posteriores) ou mesmo com os regimes democráticos que ocorreram a partir, aproximadamente, do século VI. Ademais, o fenômeno da cidade-estado não se limita ao mundo grego, notadamente no território da Hélade e nas suas colônias do Oriente e do Ocidente, na magna Grécia, tendo em vista que a "cidade-estado é, de fato, em suas origens e mesmo depois por longo tempo, a própria Roma".

Para Bonini38, as particularidades básicas da polis grega são suas relações com os organismos políticos menores, sendo estes, além da família em sentido específico, em ordem crescente de importância, os seguintes: o ghenos - conjunto dos que estão ligados a uma base familiar; a fratria - associação de famílias com encargos de defesa, assistência e culto próprio; e

\footnotetext{
${ }^{37}$ BONINI, Roberto. Noção de polis. In: BOBBIO, Norberto; et al. Dicionário de política. Brasília: UNb, 1986. ${ }^{38} \mathrm{Ibid}$., passim.
} 
a tribo - reunião de fratrias que, na ausência de um eficiente poder estatal, assume funções relevantes. Então, a polis teria se formado precisamente com o reconhecimento de uma autoridade superior a dos organismos destacados.

Em conformidade com Mumford ${ }^{39}$, a cidade antiga surge no decorrer dos processos que envolvem a transferência da ênfase do chefe para o rei, como a passagem da cultura da enxada para a do arado; tendo isso ocorrido em um longo período, antes mesmo que a cidade efetivamente dimensionada surgisse, por ocasião da consolidação de suas estruturas institucionais. Em seguida, este autor esclarece que isso teve início "[...] como uma concentração de força do trabalho sob uma chefia firme, unificada e autoconfiante, a cidade ancestral foi, antes de tudo, um instrumento para a arregimentação de homens e para o domínio da natureza, dirigindo a própria comunidade para os serviços dos deuses". Dessa maneira, Mumford entende que a polis emerge como tal a partir dos séculos VIII e VI a.C., entre os quais começou a ser traçado, por sobre o Egeu, um novo padrão urbano, tendo esse período sido marcado pela introdução do alfabeto e, por volta de 650 a.C., pela invenção da moeda cunhada. Assim, esta época foi caracterizada "por uma devolução do poder da cidadela á comunidade baseada na aldeia e pela ascensão da própria aldeia a um novo grau de consciência própria e divisão cósmica, de que dão testemunho As obras e os dias e a Teogonia de Hesíldo".

Os gregos dos séculos VII e VI a.C. especialmente, mas também os que viveram em Atenas entre o século V e o IV a.C., conceberam a polis como uma comunidade, ou seja, uma organização cujos assuntos eram do interesse coletivo. Mas, para que fosse como tal, muito contribuíram as dimensões da polis, visto que comparadas com as de uma metrópole atual, eram tão reduzidas que cada um de seus membros podia apelar diretamente, em caso de necessidade, a todos os seus cidadãos; sendo que, além desse aspecto, evidentemente que existiram outros fatores fundamentais, tais como o econômico e o político, que são imprescindíveis não só para explicar o que foi a polis, como igualmente para compreender a história da cidade ocidental. ${ }^{40}$ Nesse sentido é a concepção de Kitto ${ }^{41}$, quando faz a seguinte exposição:

Qualquer grego conhecia a polis, pois estava ali, inteira, diante dos seus olhos. Ele podia ver os campos que the forneciam seu alimento - ou que não o fornecia se as colheitas não eram boas; de modo igual, podia ver a agricultura e o comércio desenvolvendo-se harmonicamente. Além disso, conhecia as fronteiras, seus

\footnotetext{
${ }^{39}$ MUMFORD, Lewis. A cidade na história: suas origens, transformações e perspectivas. Trad. Neil R. da Silva. São Paulo: Martins Fontes, 2008. p. 113 e 149.

40 KITTO, H. D. F. The Greeks: a study of the character and history of an ancient civilization, and of the people who created it. [s.I.]: Pelican Books, 1951. Passim.

${ }^{41}$ Ibid., p.70-71.
} 
pontos mais seguros e os que eram mais fracos; assim, se existissem conspiradores que planejavam uma ação subversiva, logo isto se tornava algo público, pois era muito difícil ocultá-lo. A vida da polis, e a relação entre suas partes, era muito mais fácil de abranger, em virtude, justamente, desta pequena escala; em consequência, dizer que 'cada um tinha o dever de ajudar a polis', não era uma afirmação que exprimia um sentido belo, e sim o princípio enunciado de acordo com o mais simples evidente e urgente sentido comum. As questões públicas tinham um sentido imediato e concreto que para nós, hoje, era estranho.

Com base nesta explanação, é possível perceber que para os gregos a polis era o lugar onde o homem se realizava, diferentemente do contexto atual, no qual multidões dos grandes centros urbanos transitam pelas amplas avenidas na busca ininterrupta pela sobrevivência. Em outros termos, a partir dessas descrições, poderemos ter uma noção da distância que nos separa daquela realidade em que a polis era o espaço onde o homem chegava a ser ele mesmo. Portanto, na compreensão dos gregos, bem mais do que a esfera do trabalho (da produção), a polis foi o âmbito do encontro interpessoal, do diálogo e das celebrações; assim sendo, quando Kitto $^{42}$ analisa as dificuldades da tradução da palavra polis, enfatiza que "ela pode estar referida tanto à vida comunitária em termos políticos, culturais e morais como econômicos".

Então, a polis foi, sem dúvida, o espaço por excelência da existência grega, que a conceberam como "uma comunidade de vida baseada no parentesco real ou presumido, ou seja, uma espécie de ampliação familiar que fazia de quase toda a existência, uma experiência de intimidade"; enquanto que, na atualidade, a cidade é um mecanismo para a produção de segurança e conveniência, diferentemente da conjuntura grega, em que a polis era um lugar essencialmente formativo, que educava a mente e o caráter dos cidadãos.

Quanto ao aspecto demográfico, a polis também tinha suas particularidades, como podemos verificar nas palavras de Aristóteles $^{43}$, quando afirma que cada cidadão deve reconhecer os outros aos vê-los; além disso, salientou que "[...] uma população muito numerosa não se pode prestar ao estabelecimento da ordem, a não ser por obra de uma forma divina que é como o laço e o apoio de todo o universo". Por sua vez, Platão $0^{44}$ entendia como uma situação de absoluto desespero a manutenção de uma cidade com mais de 5.000 habitantes.

Ainda considerando o urbanismo na Grécia Antiga, é pertinente destacar que a noção de "cidade" não se confundia com a de "vila", pois, como já evidenciamos, a cidade (polis) era,

\footnotetext{
42 KITTO, 1951, passim.

${ }^{43}$ ARISTÓTELES, 2009, 1326a 30.

${ }^{44}$ PLATÃO. As Leis, incluindo Epinomis. Trad. Edson Bini. 2.ed. Bauru/SP: EDIPRO, 2010. 740e.
} 
sobretudo, uma comunidade de cidadãos, uma associação de caráter moral, político e religioso. Porém, durante muito tempo, os pensadores gregos que se interessavam pela cidade, apenas suscitavam elementos relacionados com a perspectiva da filosofia política e da moral. Hipócrates, que foi um dos pioneiros, compreendia a cidade de maneira concreta, analisando os efeitos do ambiente urbano (sítio, localização, natureza do solo etc.) sobre os habitantes, tanto no aspecto físico quanto no moral. Mas, foi somente no século IV, com Platão e Aristóteles, que se instaurou uma autêntica reflexão urbanística, como podemos ver em As Leis ${ }^{45}$, onde esse primeiro pensador estabelece princípios que devem comandar a instalação material da cidade ideal; sendo que é Aristóteles, com suas preocupações práticas, que se torna o grande teórico do urbanismo na Grécia Antiga. ${ }^{46}$

No que se refere à cidade romana, é importante inicialmente lembrar que a passagem da polis grega à urbs romana não se restringe na simples translação idiomática de um mesmo significado, tendo em vista que implica, diversamente, em um afastamento do sentido natural e humano que abrange a polis, bem como na dissolução da identidade real do sujeito em prol de sua identificação figurada. De forma que, o surgimento da existência jurídica do cidadão desencadeia a perda progressiva da concepção de pessoa concreta. De fato, Roma, pelas suas características próprias, já estava bastante distante do que foi a polis como qualquer um dos centros urbanos que surgiram muitos séculos depois. Nesse prisma, assevera Motes $^{47}$ que:

A capital romana é a cidade que atinge maior concentração demográfica em toda a antiguidade. A falta de terreno obriga à constante elevação das moradias de aluguel, e assim é como aparecem as grandes concentrações nas quais converge uma população procedente de todas as regiões ocupadas. A especulação nas construções e na compra e venda dos materiais nelas empregados representava o perigo real, e com frequência a irresponsabilidade originava grandes catástrofes por desabamento ou incêndio [...]. Do ano 264 ao 133, Roma se transforma na primeira potência mundial que atinge um domínio absoluto no Mediterrâneo, passando então a se constituir no maior foco de atração e concentração humana. Seu crescimento demográfico é extraordinário e muito superior ao ritmo previsto pelas próprias autoridades. A cidade superou rapidamente os 426 hectares que circundavam os muros servianos, e no século I a população atinge praticamente os oitocentos mil habitantes. [...] Roma oferecia o aspecto de uma imensa cidade monumental. Suas ruas representavam mais de 90 quilômetros e ocupavam uma extensão de 1.386 hectares, que, depois, ampliaram-se até atingir quase 2.000 no século seguinte. As moradias particulares somavam mais de mil e

45 PLATÃO, 2010, 741b, c e d; 745b, c e d;

${ }^{46}$ HAROUEL, Jean-Louis. História do urbanismo. Trad. Ivone Salgado. Campinas/SP: Papirus, 1990.

47 MOTES, Juan Maluquer de. O nascimento da vida urbana. [s.I.: s.d.], 1975. Passim. 
oitocentas e havia mais de cinquenta mil casas de aluguel. A população superava já um milhão de habitantes.

Indiscutivelmente, essas proporções de crescimento são significativas não apenas no que diz respeito especificamente à demografia da polis, mas também com relação ao próprio império romano no seu conjunto, que já contava com milhares de habitantes. Por conseguinte, o sentido da vida urbana, em um centro como Roma, não podia continuar sendo o mesmo que nas tradicionais cidades gregas, pois a dessacralização da vida cotidiana e a dissolução do contexto das tradições, aliada ao forte desenvolvimento militar e comercial que consolidou o império, transformaram a urbs romana em um dos exemplos paradigmáticos na história da alienação cidadã. Em resumo, a história romana se desenvolve por mais de um milênio, desde Roma primitiva até as realizações urbanas do final da República e do Império, sendo nos dois primeiros séculos da atual era que as cidades romanas atingem seu apogeu, com seu pleno desenvolvimento em matéria de qualidade de vida, notadamente naquelas cidades provincianas que não ultrapassava algumas dezenas de milhares de habitantes.

Nessa perspectiva, Haroue $^{48}$ reúne uma série de informações importantes sobre o urbanismo romano, com destaque aos seguintes aspectos: os grandes princípios - ritos de fundação das cidades (agouro, orientatio, limitatio e consagração), o plano das cidades (caracterizado pelo emprego sistemático do traçado ortogonal); elementos urbanos - a muralha, as ruas (em geral pavimentas e cercadas de calçadas), o fórum (ao mesmo tempo mercado, local de reunião e centro da vida pública, constituindo o coração da cidade romana), os equipamentos públicos (uma praça que deve ser destinada aos edifícios voltados ao lazer, ou seja, teatro, circo, anfiteatro e termas) e as habitações (domus, que é o tipo clássico da casa particular romana onde habitam uma família e seus empregados, e insulae, que são edifícios coletivos de vários andares, divididos em apartamentos de aluguel); o tratado de urbanismo de Vitrúvio - intitulado De architectura, sendo considerada a mais completa obra na seara do urbanismo que nos foi legada pela Antiguidade, que, com base nos teóricos gregos, tinha como preocupações maiores a comodidade, estética e salubridade, tratando do sítio, da exposição do ar, da água e da localização dos edifícios públicos e das casas; regime administrativo e jurídico as repartições competentes (serviços administrativos encarregados da limpeza pública e das construções, por meio dos supervisores de obras e dos magistrados), legislações urbanísticas (Lei das Doze Tábuas, que tratava da distância da propriedade vizinha para construir, da interdição e da desapropriação).

O surgimento da cidade medieval teve como aspecto precursor principal o fato de que Roma, sem condições de enfrentar os embates que foi submetida pelos seus inimigos externos,

${ }^{48}$ HAROUEL, 1990, p. 22-32. 
especialmente pelas invasões germânicas, inevitavelmente teve a queda de seu império, há muito deteriorado moral e administrativamente. Além do mais, com o fim desse período imperial, a vida urbana perdeu, durante vários séculos, progressos no âmbito das formas de organização social, voltando a tendência das pessoas se concentrarem no campo. Registre-se, que os poucos centros urbanos, em geral, ocupavam áreas territoriais inferiores a 25 hectares, sendo um conjunto compacto de casas incômodas e ruas estreitas tortuosas, que não tinham, nos séculos V, VI e VII da atual era, mais de 6.000 habitantes.

Desse modo, a cidade só readquiriu a importância no Ocidente após aproximadamente quatro séculos; sendo que, enquanto isso, a precedente visão cristã da vida e da morte começou a ganhar projeção nos séculos posteriores, preenchendo o vazio moral que predominava nesse período. Assim, para a grande maioria que habitava o campo, o ressurgimento das velhas cidades e o aparecimento de outras novas, representou uma possibilidade de libertação do domínio feudal. Consequentemente, os espaços urbanos foram sendo preenchidos e dessa forma foi como, extramuros, surgiram os burgos ou a arrabaldes populosos que rodearam as muralhas das cidades. ${ }^{49}$

$\mathrm{Na}$ Europa, o período medieval corresponde a um grande crescimento urbano, durante o qual se forma a maioria das aglomerações modernas, enquanto que no Renascimento as novas formações urbanas são menos numerosas; além disso, o urbanismo medieval e o Renascimento ${ }^{50}$ diferem profundamente em suas concepções, pois, enquanto a Idade Média prende-se à solução de programas concretos, de forma assistemática, no Renascimento, pelo contrário, observa-se a receptividade por questões de ordem prática, sempre buscando um modelo de cidade ideal a partir de uma estética urbana de valor universal.

Nessa discussão, é necessário ressaltar que a repartição da vida urbana acontecia na Europa dos séculos $X$ e XI, como consequência do crescimento demográfico. Segundo Mumford" ${ }^{51}$ a cidade antiga decaiu devido a uma "simbiose negativa apoiada na guerra, na exploração, na escravização e no parasitismo". Mas, em torno do século XI, a urbs renasce, circundada por uma muralha cuja função era conter as agressões dos invasores; de maneira que, uma vez consolidada a proteção contra as incursões e as imposições foraneas, os artesãos, camponeses e pescadores, donos de privilégios extraídos do senhor feudal, reuniam-se em uma feira semanal ou quinzenal, acabando por se instalar de forma permanente em um lugar que

\footnotetext{
49 KALINA, Eduardo; KOVADLOFF, Santiago. As ciladas da cidade. Trad. Eduardo Kovadloff. São Paulo: Brasiliense, 1978. p.36.

${ }^{50}$ Sobre o urbanismo no Período Medieval e no Renascimento, Harouel apresenta uma explanação detalhada sobre todo o processo histórico do desenvolvimento do urbanismo, desde as formas urbanas até as dimensões culturais, sociais, econômicas e políticas. Cf. HAROUEL, 1990.

${ }^{51}$ MUMFORD, 2008, p. 133.
} 
possuía várias vantagens para nele se viver. Saliente-se que, na época inicial desse período, a organização social esteve circunscrita a pequenas vilas e subúrbios, que era como se designavam os estabelecimentos agrícolas organizados próximos às muralhas dos castelos; logo, as fontes do trabalho rural foram ocupadas, enquanto que a atividade comercial começou a ganhar uma certa projeção, causando assim a indignação de um verdadeiro romano.

De fato, de acordo com a interpretação de Mumford"52, "não foi, porém, o renascimento do comércio no século XI o que determinou a fundação de um novo tipo de cidade, pois se estabeleceram muitos centros antes deste acontecimento". Continuando, explica este autor que "a atividade comercial era o sintoma de um renascimento muito mais importante que, naquele momento, estava se produzindo na civilização ocidental", exteriorizado pelo novo sentido de segurança oferecido pela cidade amuralhada.

Registre-se, também, que o monopólio que a atividade rural tinha com relação à produção de matérias primas, muito influenciou a concentração nas cidades de práticas manufatureiras, artesanais e comerciais propriamente ditas. A partir dessa realidade, a cidade começa a adquirir um caráter predominantemente econômico, transformando-se, gradativamente, em um centro de trabalho. Em outras palavras, intensifica-se o afastamento entre esta cidade e a outra concebida como polis, como já descrevemos antes; então, a cidade torna-se, diferentemente do que acontecia entre os gregos, o lugar da transação, do intercâmbio e do cálculo. Nessa conjuntura, a noção de profissão passa a definir a essência da pessoa, ou seja, para se dizer quem é, o homem deve dizer o que faz; de modo que, o cidadão passa a ser, antes de mais nada, o homem ativamente integrado ao processo produtivo. Por sua vez, a cidade não apresenta características de conforto e beleza, que a distinguiu no passado, pois é, sobretudo, um lugar onde, mais do que viver, sobrevive-se. Nesse sentido, afirma Motes $^{53}$ que "as ruas eram, na maioria dos casos, empinadas, estreitas e escuras, pois os tetos salientes Ihes roubavam a luz. Algumas delas estavam cobertas por pedras não trabalhadas, e outras eram, simplesmente, de terra. Muito poucas possuíam esgotos".

Outrossim, nessa abordagem é de extrema relevância destacar a origem da burguesia que, considerada como sendo uma classe social plenamente urbana, remonta a experiência histórica dos servos da gleba, que a partir dos séculos IX e X tornaram-se homens livres. No decorrer da Idade Média, eles foram chegando às cidades, em busca de novas condições de vida e de trabalho; sendo que, com relação a este último aspecto, cumpre salientar que aqueles que chegavam, se encontraram com agrupamentos organizados, possibilitando assim o desenvolvimento de suas atividades, obrigando-os a se submeterem as disposições legais que

\footnotetext{
52 Ibid., p. 123 et seq.

53 MOTES, 1985, p.87.
} 
impunham as agremiações existentes para cada uma das profissões. Por conseguinte, tal condicionamento colocou-os em uma situação que muito repercutiu em suas condições de vida, até o surgimento do que, alguns séculos depois, Marx ${ }^{54}$ chamou de "condições de classe". Com efeito, para este autor, "os diferentes indivíduos somente formam uma classe quando se veem obrigados a manter uma luta comum contra outra classe, já que - não sendo assim - eles acabam se enfrentando uns aos outros, de maneira hostil, no plano da competência".

Portanto, com a crescente intervenção da burguesia na indústria manufatureira e a amplitude que foi ganhando o intercâmbio entre as cidades, o comércio adquiriu uma reconhecida significação política. Nessa linha de pensamento, esclarece Marx que "o comércio e a manufatura criam a grande burguesia, que agora já não continuava dominando, como antes, nas cidades, senão que tinha que aceitar a hegemonia dos grandes comerciantes e manufatureiros". Dessa forma, é possível observar que a expansão do capitalismo industrial no século XIX em todo o Velho Mundo foi o grande responsável pelo contínuo crescimento populacional nas grandes cidades, bem como pela formação de novos centros metropolitanos, representando, então, o surgimento da denominada cidade industrial ${ }^{55}$, que inclusive já destacamos no tópico anterior deste trabalho.

O percurso histórico das cidades medievais às do Renascimento, e o destas às da Idade Moderna Clássica (séculos XVIII e XIX), demonstrou claramente até que ponto a vida urbana encontra-se inter-relacionada com interesses econômicos, especificamente com os da classe burguesa - que foram determinantes na construção do significado conferido à vida e às relações sociais, incluindo os aspectos culturais, econômicos e políticos. Assim, o ingresso das sociedades europeias na era industrial no decorrer do século XIX intensificou as já preocupantes condições de existência de uma vida digna, notadamente para o trabalhador dependente.

Sobre o surgimento da cidade atual, Sassen ${ }^{56}$ enumera três importantes fatos que ocorreram nos últimos 25 anos, considerado por ela uma conjuntura própria das operações econômicas. Dessa maneira, relata essa autora que o primeiro deles é a "dispersão territorial das atividades econômicas, das quais a globalização é uma das formas" que, por sua vez, contribuiu "para o aparecimento das funções e operações centralizadas". O outro é o "gerenciamento e controle centralizado sobre um conjunto geograficamente disperso de operações econômicas" que "não ocorreram inevitavelmente como parte de um sistema

\footnotetext{
${ }^{54}$ MARX, Karl. Manuscritos econômicos-filosóficos e outros textos escolhidos: salário, preço e lucro. Trad. Leandro Konder. v.2. 4.ed. São Paulo: Nova Cultural, 1988. p. 101 e 104-105.

${ }^{55}$ Com relação à cidade industrial, Benevolo desenvolve uma importante abordagem sobre o urbanismo moderno, destacando especialmente a formação da cidade industrial. BENEVOLO, 1983, p. 13 et seq.

${ }^{56}$ SASSEN, Saskia. As cidades na economia mundial. São Paulo: Nobel, 1996. p.153-154.
} 
mundial". Por último, elenca o fato que "a globalização econômica contribuiu para uma nova geografia da centralidade e da marginalidade".

Enfim, com base nas considerações apresentadas por Sassen, é compreensível que esses fatos são responsáveis pela consolidação da cidade, sobretudo a metrópole ou a cidade global ${ }^{57}$, onde há extrema concentração de diversidades sociais, econômicas, culturais e políticas. Mas, ao término da análise retrospectiva da formação das cidades, desde a antiga até as cidades atuais, passaremos a estudar o desenvolvimento das cidades brasileiras, partindo do período colonial e chegando a tendência modernista modelo, representada por Brasília.

\section{A ORIGEM DAS CIDADES BRASILEIRAS}

No Brasil, a política territorial latifundiária foi a base do sistema de colonização, pois, devido à extensão territorial, os sesmeiros eram "donos" de grandes glebas de terra, que eram delimitadas em léguas quadradas. Assim, havia uma ampla prioridade para a vida rural, sendo a habitação nas cidades considerada antinatural. Mas, diversamente da tendência geral, inclusive da colonização espanhola, os portugueses não asseguraram os predomínios militar, econômico e político da metrópole mediante a criação de grandes núcleos urbanos, tendo em vista que as ordenações do Reino fixavam seus próprios princípios sobre o estabelecimento das povoações. 58

Com a Resolução de 17 de julho de 1822, houve a extinção do regime de sesmarias no território brasileiro, sendo que, mesmo com a Proclamação da Independência, continuavam em vigor às Ordenações Filipinas e demais decretos editados até 25 de abril de 1821. Já em 18 de setembro de 1850, foi decretada pela Assembleia Geral e sancionada pelo Imperador, a denominada Lei da Terra (Lei n.601). Registre-se que, no período entre o término do sistema de sesmarias e a vigência da nova lei, houve um intervalo designado pelos doutrinadores de extralegal ou de posses, caracterizado pela inexistência de uma legislação de terras no Brasil. ${ }^{59}$

De um modo geral, no Brasil colonial apenas os núcleos urbanísticos litorâneos se desenvolviam a partir do assentamento espontâneo das populações, que firmavam pequenos

\footnotetext{
57 Quanto à metrópole e a cidade global, é pertinente registrar a concepção de Megalópolis, presente nos trabalhos de Mumford. MUMFORD, 1961; __ 2008. V.tb. a perspectiva da cidade pós-moderna, no trabalho de Harvey, onde desenvolve uma explanação sobre arquitetura e projeto urbano. HARVEY, David. Condição pós-moderna. Trad. Adail Ubirajara Sobral; Maria Stela Gonçalves. 12.ed. São Paulo: Loyola, 2003, p.69 et seq.; COELHO, Teixeira. Moderno, pós-moderno: modos e versões. 4.ed. São Paulo: Iluminuras Ltda, 2001. p. 61-78.

58 HOLANDA, Sérgio Buarque de. Raízes do Brasil. 26.ed. São Paulo:Companhia das Letras, 1995. p.95 e 98.

59 LIRA. Ricardo Pereira. Elementos de direito urbanístico. Rio de Janeiro:Renovar, 1977. p.318; v.tb. MARICATO, Ermínia. Habitações e cidade. São Paulo: Atual, 1990. p.22-23; As ideias fora do lugar e o lugar fora das ideias: planejamento urbano no Brasil. In: ; ARANTES, O; VAINER, C. A cidade do pensamento único: desmanchando consensos. 5. ed. Petrópolis: Vozes, 2009. p.148-149.
} 
povoamentos na costa. Nessa perspectiva, Silva ${ }^{60}$ faz a seguinte explanação sobre os assentamentos urbanos brasileiros no período colonial:

O fenômeno urbano vincula-se à política de ocupação e povoamento da Colônia e sua evolução liga-se aos ciclos econômicos brasileiros. O sistema inicial de exploração grosseira dos recursos naturais (pau-brasil) deu origem às primeiras feitorias e alguns agrupamentos humanos com rendimento de agricultura. Com a expedição colonizadora, Martim Afonso funda São Vicente, dando início à formação de vilas e povoados, de sorte que, à época da instalação do Governo Geral (1549), já haviam sido fundados 16 povoados e vilas no litoral brasileiro, e Tomé de Souza chega e funda a cidade de Salvador.

Saliente-se, porém, que apesar da formação inicial de alguns povoados e vilas, "a estrutura de nossa sociedade colonial teve sua base fora dos meios urbanos" 61; até porque, povoar constituía o grande desafio, a que se submetiam todos os demais interesses. Nesse sentido, Vianna apud Silva ${ }^{62}$ atribui ao homem colonial uma "tendência antiurbanizante", como sendo uma decorrência natural do sistema colonial de povoamento e distribuição de terras em "sesmarias". Dessa forma, no decorrer da sua análise, esse autor afirma que

Esta estruturação ecológica sob a qual evoluiu a nossa população colonial, caracterizada pela rarefação e adelgaçamento da massa povoadora, pela dispersão dos moradores por uma base territorial imensa e inculta, apenas percorrida pelo povo-massa carente quase em absoluto de comunicações espirituais, tinha que acabar, como acabou, por enformar o homem, criando-lhe um tipo humano adequado a esta disposição dispersiva, individualista e atomística. E criou o homo colonialis, amante da solidão e do deserto, rústico e antiurbano.

Diante dessa realidade conjuntural, a política povoadora implantada por Portugal era ineficiente, pois os grupos sociais que aportavam no litoral brasileiro não satisfaziam as necessidades de um território já em expansão. Com efeito, é neste ponto de vista o pensamento de Ferreira ${ }^{63}$ quando esclarece que:

[...] não era possível contar com as correntes emigratórias de Portugal, senão em contingentes insignificantes e espaçados. Achava-se o problema por isso mesmo em perene ordem do dia nas sessões das Câmaras. As de São Vicente e de Santos representaram, em 1581, a Jerônimo Leitão, governador da Capitania, como lugar tenente do donatário, chamando-Ihe a atenção para o despovoamento de suas vilas. A escravatura, ultrapassante de duas mil

60 SILVA, José Afonso. Direito Urbanístico Brasileiro. 2.ed. São Paulo: Malheiros, 1997. p.21.

61 HOLANDA, 1995, p. 73.

62 VIANNA, Oliveira apud Silva, José Afonso da. Op. cit. p.21.

${ }^{63}$ FERREIRA, Waldemar Martins. História do direito brasileiro. Tomo I. Rio de Janeiro: Freitas Bastos. 1951. p.10. 
peças, se achava decrescida pelas mortes ocasionadas por doenças conhecidas.

De maneira que, a metrópole acabou implementando uma política colonial contraditória, na medida em que pretendia instaurar o regime municipalista, incentivando as práticas de povoação e instalação de vilas; mas, em sentido contrário, adotava um sistema de distribuição de terras em sesmarias que isolava o homem. Por conseguinte, fica evidente que o processo urbanístico brasileiro, oriundo da lógica de assentamento utilizada por Portugal nos primórdios de nossa colonização, foi equivocado, haja vista que, a dispersão provocada pelos assentamentos rurais, principalmente aqueles que formavam os núcleos dos engenhos, resultou na constituição de um modelo autárquico que formou a base da estrutura social do nosso país.

No âmbito brasileiro, dependendo dos momentos histórico, social, econômico e político, existiram várias formas de aglomerações humanas, sendo que era o predomínio de alguns desses fatores que influenciavam os padrões de ocupação em detrimento dos demais. Além do mais, a qualidade ambiental também teve sua intensidade e conotação absolutamente distintas, passando de um equilíbrio com a natureza, como é o caso das aldeias indígenas, para situações de impacto ambiental, anunciadas como "desenvolvimento" no início do século XX, que persistiram até a conscientização e consequentes restrições das situações consideradas impactantes, isso notadamente a partir das décadas de 60 e 70 do século passado.

De fato, as aldeias indígenas eram e ainda são construídas guardando uma relação de equilíbrio com o ambiente natural ${ }^{64}$, tendo a região Centro-Oeste e a Amazônia como exemplos, onde as ocas geralmente não possuem janelas. Tal fato é explicado por Villas Boas ${ }^{65}$, sendo que a princípio pode até causar uma certa estranheza, visto que em climas quentes, nos quais a ventilação é essencial, a ausência de janelas se configura como um problema. Todavia, observando melhor o comportamento indígena, esse pesquisador conclui que o aspecto dos índios primitivos não possuírem roupas está diretamente relacionado com a preocupação com a friagem da madrugada, momento em que o índio se encontra dormindo, com o metabolismo fisiológico reduzido pela ausência da atividade física, aumentando então a necessidade de abrigo. Além disso, registre-se que as ocas, além de não possuírem janelas, no seu interior também são acesas fogueiras, objetivando combater os insetos e a friagem.

Em síntese, o índio brasileiro praticava a coivara e queimava a vegetação para plantar, derrubava árvores para fazer suas aldeias (ocas) e matava animais para sua alimentação, exteriorizando assim um comportamento predatório; contudo, na sua relação com o ambiente

\footnotetext{
64 JONAS, 2006, passim.

65 VILLAS BOAS, Márcio. Significado da arquitetura nos trópicos: um enfoque bioclimático. In: Boletim do Instituto de Arquitetura e Urbanismo. Brasília: UnB, 1986.
} 
natural havia um certo equilíbrio devido, em parte, à baixa densidade de ocupação e também em função de sua cultura ter como base a necessidade direta do meio ambiente natural. Saliente-se que este aspecto tinha uma especial importância nessas aglomerações humanas, não apenas na implantação da aldeia próxima às fontes de água, mas igualmente pela fixação em áreas de caça e pesca abundante, localizadas predominantemente em lugares que não estavam sujeitos às inundações. Ademais é pertinente destacar a relevância dos fatores naturais, pois todos os materiais utilizados na construção da aldeia e de seus utensílios são retirados diretamente da natureza, assumindo, no caso da oca, a função de proteção contra a chuva, o sol e o frio, como já ressaltado; de forma que, estes três aspectos, juntamente com a vegetação, há bastante tempo orientam as construções e ocupações humanas. Sem dúvida, durante mais de 5 mil anos os índios brasileiros conviveram com a natureza tropical, dela tirando a sua sobrevivência e nela se inserindo como parte integrante. Porém, com a chegada do europeu, notadamente a partir do século XVI, portugueses em particular, observou-se uma nova forma de ocupação dos espaços ${ }^{66}$.

Em geral, a selva tropical assustava o colonizador, devido ao seu gigantismo e ação dos animais peçonhentos, bem como pelos ataques dos índios. Consequentemente, a floresta passou a constituir um inimigo mortal, da mesma forma que sua derrubada significava a civilização, o desenvolvimento; portanto, somente no século XVIII é que se começou a discussão sobre programas de arborização urbana, com um significativo enfoque relacionado com a realidade europeia. Então, de início, as atividades de extração do pau-brasil e mesmo a plantação de cana-de-açúcar não foram suficientes para a formação de grandes cidades ou de uma rede urbana significativa. Mas, de qualquer modo, na costa brasileira surgiram postos estratégicos, núcleos urbanos e fortificações que tinham a finalidade básica de proteção territorial, isso sempre em uma perspectiva competitiva com a mata; sendo pertinente lembrar que, nesse processo de evolução da estruturação urbana, o aspecto natural (sítio) foi de fundamental importância.

Assim sendo, no início da formação urbana brasileira, as cidades tinham a função primordial de defesa do território, localizando-se geralmente nas partes mais altas, como a cidade do Rio de Janeiro, que teve sua fundação no íngreme morro do Castelo. Além do mais, o fato de grande parte do terreno se encontrar alagado e naquela época não se dispor de tecnologia para uma rápida construção nessas localidades, contribuiu para a forma de implantação das cidades em áreas mais elevadas. Dessa maneira, a forma urbana ganhava características próprias a partir das construções em sítios acidentados, sendo o aspecto natural

66 GOUVÊA, Luiz Alberto. Biocidade:conceitos e critérios para um desenho ambiental urbano, em localidades de clima tropical de planalto. São Paulo: Nobel, 2002. p.14-15 
relevante na determinação da configuração das cidades, exercendo também influência os elementos simbólicos, de controle e econômicos, expressos por meio da localização (fácil visualização) das fortificações, como também por intermédio de cidades portuárias como Recife, Salvador, Rio de Janeiro etc.

Ainda no período colonial, nos séculos XVII e XVIII, o aspecto natural teve grande importância na forma dos núcleos urbanos, tendo em vista que, com a interiorização, a procura de ouro e a caça ao índio passaram a gerar um movimento para o interior do país. Com efeito, isso acabou induzindo a criação de uma de rede urbana fora do litoral, em muitos casos, em áreas de relevo acidentado, inclusive próximo às zonas de mineração em que os traçados urbanos tiveram de se adaptar. Nesse contexto, Saint-Hilaire ${ }^{67}$ descreve Luziânia (Santa Luzia 1819) do seguinte modo:

Não devemos julgar as povoações do interior do Brasil pelas nossas, que em geral não oferecem mais do que uma reunião de cabanas e ruas lamacentas. A maioria das povoações de Minas e Goiás, que devem suas origens as minas de ouro, devem ter sido encantadoras no tempo do seu esplendor, e Santa Luzia, certamente, foi uma das mais agradáveis: suas ruas são bastante largas e regulares; as casas, em número de cerca de trezentas, são, na verdade, construídas de pau e barro, sendo menores e mais baixas que as das povoações que percorrera até então; mas, são todas cobertas de telhas, recobertas com esta terra branca que chamam tabatinga no interior do Brasil, e algumas têm nas janelas caixilhos de algo tão transparente como o vidro.

Certamente, essas cidades funcionaram para o colonizador como instrumentos de controle da exploração aurífera no interior do país, tendo, por conseguinte, nas questões ideológicas, comportamentais e econômicas, as principais influências de sua configuração urbana. Além disso, a imponência dos edifícios e a riqueza das igrejas eram alguns dos indicadores dos aspectos que integravam a forma das cidades. De modo igual, o elemento natural também já se fazia presente, haja vista que essas cidades, construídas próximas às áreas de garimpo e que normalmente eram muito acidentadas, refletiam as dificuldades decorrentes do relevo. Tomemos, como exemplo, as cidades implantadas nas áreas de garimpo de Goiás, que eram possuidoras de íngreme topografia, onde a estrutura urbana foi se adaptando à declividade do terreno, em muitas situações guardando, inclusive, uma distância adequada dos vales que eram inundados pelos rios, preservando assim as matas ciliares ali existentes.

Nas cidades coloniais, os quintais apareciam como grandes espaços verdes, onde as sombras das árvores frutíferas suavizavam os rigores do clima e ainda propiciavam o necessário

${ }^{67}$ SAINT-HILAIRE, Auguste de. Viagens às nascentes do Rio São Francisco e pela província de Goiás. Tomo II, v.78. São Paulo: Cia. Editora Nacional, 1937. p.35. 
umedecimento do ambiente. Nessas áreas apareciam com frequência as hortas, incluindo uma parte medicinal, com que tradicionalmente tratavam as enfermidades da família. Já as ruas principais, eram calçadas com pedra, o que permitia uma infiltração das águas pluviais no solo; porém, na época atual, com a introdução indiscriminada do calçamento asfáltico em grande parte das cidades brasileiras, houve uma elevação significativa da temperatura ambiente.

Portanto, é necessário perceber que o modelo de cidade inspirado na concepção medieval europeia trouxe uma série de problemas ambientais para a cidade colonial brasileira. De fato, o traçado da cidade medieval, muito embora estivesse integrado ao clima temperado ou frio da Europa, com suas ruas tortuosas dificultando a penetração do vento frio; porém, no Brasil, diversamente, a transposição direta da mesma configuração urbana se constituiu em um equívoco, devido às condições climáticas com características opostas, onde o vento exerce o papel de amenizar o calor tropical. Além deste aspecto, a radiação diurna criava um certo desconforto para os transeuntes, que era minimizado, muitas vezes, pela estreiteza da maioria das ruas existentes naquela época.

Ressalte-se, também, o fato de que se não era comum a prática de plantar árvores na frente das residências, a vinda da Missão Francesa para o Rio de Janeiro, no século XIX, somente veio agravar a situação do ponto de vista ambiental; pois, apesar de introduzir o jardim frontal ou lateral e o recuo das residências, incentivou igualmente a prática dos jardins à moda europeia, de vegetação de tamanho pequeno e plantada em canteiros, o que resultou na derrubada de centenas de árvores frutíferas nos quintais brasileiros, para a adaptação dos pequenos canteiros floridos. Ademais, o edifício perdeu os beirais, recebendo a platibanda decorativa que expunha a casa aos rigores climáticos, do sol e da chuva ${ }^{68}$; por outro lado, na casa colonial brasileira era comum o uso de ventilação por meio dos forros e telhas, bem como por intermédio do uso de treliças de madeira nas janelas, que funcionavam como elementos que permitiam a passagem do ar quente, possibilitando a aeração natural da casa. Em geral, na organização da cidade colonial preponderaram os valores estéticos, ideológicos e econômicos sobre os aspectos naturais (climáticos), com grande prejuízo para a qualidade ambiental urbana. Mas, esse modelo de cidade dominou a paisagem urbana durante séculos, influenciando até os dias atuais o padrão de qualidade ambiental da população brasileira.

$\mathrm{Na}$ área rural, nas periferias das cidades e por todo o interior do país, começou também a ser construída a casa do caboclo que, como a oca indígena, apresentava excelente adaptação ao meio ambiente, sendo essas casas construídas com barro e madeira, na técnica denominada

${ }^{68}$ REIS, F. Quadro da arquitetura no Brasil. São Paulo: Perspectiva, 1970. p. 15. 
"taipa" ${ }^{69}$ Entre os elementos naturais utilizados, assim como na habitação indígena, destaca-se a importância dos vegetais, com cada região brasileira tendo variedades próprias dos materiais, em função da flora local. Registre-se, que a casa cabocla guarda a simplicidade da oca indígena, tendo poucos móveis; mas, por outro lado, se apropriou do modelo da casa europeia, utilizando portas e janelas como vias de acesso, iluminação e ventilação, bem como, diferentemente do índio, o caboclo desenvolvia uma série de atividades domésticas no interior da casa. ${ }^{70}$

Nesse sentido, quando Saint-Hilaire se referia às casas brasileiras em pequenas cidades de Minas e Goiás como "cabanas", sem querer, estava elogiando uma técnica que, apesar de ser diferente do que se conhecia e precisava na Europa, estava plenamente adaptada ao clima tropical brasileiro, não apenas pelos materiais utilizados, como também pela sua integração com o entorno, quase sempre frondosamente arborizado.

A casa colonial introduzida pelos portugueses na área rural brasileira evoluiu no decorrer do tempo, além de ser um importante instrumento do colonizador para a penetração e estabelecimento, notadamente no interior do sertão brasileiro. Um aspecto interessante nesse tipo de habitação é que, apesar de já utilizar elementos construtivos mais sofisticados do que a oca indígena ou a casa do caboclo, sua simplicidade e adequação ao meio ambiente tropical é notável, desde os grandes telhados de barro, que propiciam uma perfeita aeração e proteção contra o sol e as fortes chuvas, até as paredes de taipa ou adobe (grandes tijolos de argila), que funcionam como eficiente elemento térmico, minimizando, tanto os efeitos negativos do frio quanto do calor. Ademais, os grandes beirais e as generosas varandas ainda completavam a habitação, protegendo as paredes externas do sol e da chuva, bem como criando ambientes agradáveis, principalmente, quando associados ao uso de vegetação arbórea contígua. Enfatize-se, igualmente, que a construção da casa colonial era realizada quase que integralmente com materiais locais, frequentemente encontrados no território, permitindo, da mesma forma que as demais edificações realizadas naquele período, o equilíbrio ambiental; de modo que, isso tanto revelava a relevância dos elementos vegetais, como tinha a finalidade de servir como instrumento do colonizador para se estabelecer no território brasileiro. Assim, a identificação desses edifícios com o elemento natural foi criando uma cultura positiva de relação com a natureza, que contemporaneamente é assimilada e reinterpretada pela arquitetura regionalista, formando então juízos de valores em termos de qualidade ambiental.

\footnotetext{
69 Processo de construção de paredes que utiliza barro amassado (cru ou cozido) para preencher os espaços criados por uma espécie de gradeamento formado por paus, varas, bambus, caules e arbustos etc. Cf. HOUAISS, Antônio; VILLAR, Mauro de Sales. Dicionário Houaiss da Língua Portuguesa. Rio de Janeiro: Objetiva, 2001. p. 2659.

${ }^{70}$ GOUVÊIA, 2002, P.19-20.
} 
Em suma, compreendemos que, no período colonial, a forma das cidades, como um todo, sofreu influência de questões econômicas e ideológicas, que visavam estruturar as construções nas cidades como elementos de controle do território, dominação e exploração da população (cobrança dos impostos). Além disso, os aspectos naturais (sítios e clima) induziram muitas ações e modelos urbanos no Brasil, sendo referência para os padrões de qualidade ambiental.

Mas, com o passar do tempo, tanto a necessidade de defesa da costa de iminentes ataques, quanto à cidade construída no interior, planejada pela Coroa especialmente para a coleta de impostos, foram minimizadas com a independência do Brasil. Dessa maneira, no século XIX ${ }^{71}$ as cidades começaram a ser implantadas objetivando outros parâmetros, que não o controle e defesa do território, com os elementos econômicos passando a ter um significado maior no momento da escolha do sítio, pois não se tinha mais aquela opção determinada para construir as cidades sobre um relevo íngreme que caracterizou a época anterior. Logo, nesse período, era possível fazer a opção por sítios menos acidentados e mais adequados à urbanização, com o solo passando a ter valor comercial, tendo este influenciado decisivamente a organização do espaço urbano.

No final do século XIX e início do século XX, surgem principalmente no interior do país e em particular nas regiões Sudeste e Sul, várias cidades com o já milenar traçado xadrez. ${ }^{72} \mathrm{Na}$ conjuntura econômica, o Brasil assumia a dianteira na exportação de café, se destacando no cenário mundial como país produtor e exportador de matérias-primas. Então, durante as cinco primeiras décadas do século passado, impulsionadas pelo crescimento da economia cafeeira existente principalmente nessas regiões brasileiras, apareceram inúmeras cidades com o modelo de planejamento urbano em xadrez (Bauru, Marília, Londrina), tendo, posteriormente, também surgida esta forma urbana no Centro-Oeste (Catalão, Gurupi, Goianésia), em decorrência do desenvolvimento agropecuário e devido à implantação da estrada Belém/Brasília.

Com efeito, a partir do momento em que não se necessitou construir em relevo acidentado e a terra urbana passou a ter um crescente valor de troca, o modelo urbano xadrez se apresentou como ótima opção, trazendo as seguintes vantagens em relação ao traçado colonial irregular: facilidade na implantação do projeto, flexibilidade para suportar mudanças, possibilidade de ampla expansão, além de oferecer melhores condições para a negociação. Em

\footnotetext{
${ }^{71}$ Encontramos no prefácio do trabalho de Freyre importante ilustração de um sobrado patriarcal semiurbano, que era comum na segunda metade do século XIX. Cf. FREYRE, Gilberto. Sobrados e mucambos: decadência do patriarcado rural e desenvolvimento do urbano. 5.ed. Rio de Janeiro: José Olympio, 1977. (Introdução à história da sociedade patriarcal no Brasil, tomo 2)

72 HAROUEL, 1990, p. 14 et seq.; 23 et seq.
} 
outras palavras, os lotes retilíneos, sem ângulos ou curvos, simplificavam o cálculo das áreas territoriais e facilitavam o registro em cartório, bem como a sua rápida comercialização. Nessa perspectiva, esclarece Mumford ${ }^{73}$ que a "planta baixa especulativa" tem na dimensão econômica prevalência sobre as outras questões, em particular no que tange aos aspectos naturais.

Sem dúvida, apesar da disposição urbana em xadrez ter seu uso testado e aprovado milenariamente (os gregos e os romanos já o utilizavam, como também os espanhóis na colonização da América), essa proposta urbana apresentava inconvenientes ambientais quando implantado em sítios acidentados. Houve casos que, quando estruturados em terrenos com topografia íngreme e em solos friáveis, provocaram excessiva erosão, acarretando grandes problemas ambientais, com altos custos de correção. Saliente-se que, naquele período, os impactos e demais situações geradas pelos planejamentos urbanos xadrez, não foram entendidos como hoje o são, pois a facilidade de implantação, execução e comercialização possibilitada por esse modelo urbano se coadunava com os ideais da época, que necessitavam adotar os símbolos de desenvolvimento das nações dominantes e fundamentalmente expandirse economicamente; já por outro lado, esse desenho criava facilidades para o encontro das pessoas no espaço urbano, fator que historicamente qualificou a cidade em relação ao campo. Em resumo, é possível afirmar que foram os fatores econômicos e tecnológicos relacionados com o modo de produção e desenvolvimento que influenciaram a forma da cidade xadrez, haja vista que esta modalidade de planejamento urbano tem a característica principal de, como já destacado anteriormente, facilidade de implantação, comercialização e expansão, enquanto que os aspectos naturais tinham uma importância secundária na história de organização dos núcleos urbanos com modelo xadrez.

De forma que, a partir das primeiras décadas do século $X X$, tanto o planejamento urbano xadrez e, principalmente, o colonial, passaram a apresentar inúmeros problemas no atendimento às exigências urbanas no Brasil; sendo que essa tendência se agravou depois da década de 1930, com a utilização dos veículos automotores e com o aumento das estruturas (maior verticalização) dos edifícios, possibilitado pelas novas tecnologias de construção, com emprego do aço e concreto, bem como pela circulação vertical (elevador). Mas, por sua vez, a densidade urbana igualmente cresceu, elevando-se concomitantemente os índices de epidemias nas cidades. Consequentemente, para solucionar tais problemas, vieram as intervenções urbanas inspiradas no "Plano de Paris", como também baseadas nas "Cidades

\footnotetext{
${ }^{73}$ MUMFORD, 2008, p. 501 et seq.
} 
Jardins", surgindo assim ideias que deram origem às cidades como Goiânia (GO), Volta Redonda (RJ), entre outras.

A proposta da Cidade Jardim buscava apresentar respostas físicas de planejamento urbano aos problemas modernos gerados com a industrialização, com a consequente migração do campo para a cidade, como também devido ao aumento exagerado dos núcleos urbanos, procurando, de um modo geral, não criar uma ruptura cultural com o já existente. Indiscutivelmente, a ideia da "Cidade Jardim" é uma ação conciliadora; tomemos como exemplo a cidade de Goiânia, construída na década de 1930 para sediar a capital do Estado de Goiás, visto que ela exterioriza bem essa proposta urbana. De fato, por um lado, seu formato contempla, com eixos de acesso rápido e dispostos radialmente, as necessidades de mobilidade do tráfego da área central e, por outro, dispõe de ruas residenciais tortuosas, perfeitamente adaptadas à topografia local. Logo, nessa disposição urbana, o aspecto natural (sítio) foi atendido, como também o critério climático foi observado, por meio da distribuição dos lotes e pelas generosas dimensões das calçadas, abundantemente arborizadas, criando uma situação climática redutora dos rigores da forte radiação diurna.

De acordo com as considerações expostas, percebemos que a organização do espaço urbano por meio da idealização da "Cidade Jardim" se revela como uma prática urbana de conciliação entre fatores naturais, sociais e locais, e as funções da cidade moderna, minimizando a separação das atividades e valorizando a relação com a natureza a custos altos, gerando assim certos níveis de segregação social dos espaços. Realmente, este aspecto e os impactos ambientais são fatos antigos no território nacional brasileiro, como foi a situação evidenciada no século XVII, quando os índios Tupis e Guaranis foram expulsos do litoral pelos colonizadores europeus, tendo de se agruparem em outras comunidades do interior do Brasil. Nessa perspectiva, é importante igualmente ressaltar que o colonizador europeu e o bandeirante trataram o índio de forma degradante, tentando escravizá-lo e destruir sua cultura; em consequência disso, desde aquela época já houve um aprendizado de como segregar para locais distantes aqueles que, apesar de ocupantes naturais da terra, não mais serviam aos propósitos do colonizador. Analogamente, a cidade moderna, definida em todo o seu significado pela nossa capital atual, Brasília, retoma a noção do colonizador. Então, como alguém que toma posse de um território, define-se o planejamento básico da cidade e se passa a segregar os trabalhadores que, tais como os índios, foram empurrados para as periferias distantes (cidades satélites). Por outro lado, apesar dos impactos sociais e ambientais advindos com a implantação, a estrutura urbana de Brasília avançava, com o projeto de uma grande área verde. 
Logo, o desenho da Cidade Jardim funcionou como alternativa diante às novas exigências da era industrial, sendo que foi do movimento moderno, iniciado nas décadas iniciais do século XX, que as cidades tradicionais (Xadrez e Colonial) sofreram as maiores críticas. Com efeito, as ideias reunidas no Congresso Internacional de Arquitetura Moderna (CIAM) de 1928, basicamente reiteradas na Carta de Atenas (1933), defendiam uma arquitetura e urbanismo que exteriorizassem o modo de produção industrial; por conseguinte, o pavimento tipo, a ausência de ornamentos e a utilização do aço, vidro e concreto, passaram a ser a regra para a construção das edificações, tendo a eficiência a partir do paradigma da racionalidade instrumental científica como palavra de ordem. Mais especificamente com relação ao urbanismo, recomendava-se a separação das funções da cidade, com a setorização separando, o máximo possível, as atividades de trabalhar, habitar, circular e recrear. Tal estratégia de projeto passou a funcionar como norma para as cidades modernistas, sendo isso uma resposta à excessiva sobreposição de atividades das cidades tradicionais, que causavam problemas sanitário, social e ambiental. Portanto, procurava-se pregar a ideia de que as cidades tradicionais estavam doentes, desprezando-se tudo que se relacionava ao passado, rejeitandose até mesmo a própria história, pois somente o novo era valorizado.

Enfim, Brasília representa um dos modelos mais completos das propostas modernistas, sendo inclusive tombada pela Unesco, como Patrimônio da Humanidade, por ser um exemplo acabado e vivo do urbanismo moderno. De um modo geral, a cidade foi estruturada basicamente por dois eixos: o Monumental e o Rodoviário, tendo o primeiro deles a concentração dos edifícios, nos quais se desenvolvem as atividades administrativas, intercalados por amplas áreas verdes, onde a natureza se apresenta sob a forma de extensos gramados, mas que permitem a não-impermealização do solo, funcionando para conter erosões. No encontro dos dois eixos, ocorrem as funções de serviços (setores comercial, hospitalar, bancário, diversões etc.). Já no Eixo Rodoviário, se estende de forma setorizada a atividade residencial, com áreas destinadas também ao comércio local e aos equipamentos comunitários.

Portanto, ao estudarmos o percurso histórico do desenvolvimento urbano das cidades brasileiras, iremos, no próximo e último tópico, desenvolver uma abordagem sobre as principais correntes teóricas que procuram fundamentar as transformações das cidades, enfatizando as tendências das formações urbanas contemporâneas.

\section{TEORIAS DAS CIDADES: TENDÊNCIAS CONTEMPORÂNEAS}


O urbanismo que tem como pretensão ser uma ciência dos estabelecimentos humanos, nasce em decorrência da Revolução Industrial, que tem início na Inglaterra a partir do século XVIII, lançando toda uma população operária nas cidades, que não estão preparadas para acomodá-la. Consequentemente, ocorre uma proliferação de cortiços, com as famílias operárias agrupando-se em locais estreitos e sem conforto, ou mesmo em subsolos insalubres. Nesse contexto, Harouel $^{74}$ enfatiza que:

Aos olhos dos contemporâneos, é toda a cidade que está doente. Ela é considerada um tecido patológico, doentio. Em Ilusions Perdués, Balzac qualifica Paris de "cancro". Médicos, filantropos, sociólogos, economistas, romancistas, diante das epidemias e da delinquência, veem aí os frutos envenenados dos cortiços, as infecções de uma cidade má, acusada de corromper a raça humana, de destilar o vício e o crime.

Sem dúvida, com todas essas preocupações, uma série de pensadores passou a repudiar a noção tradicional de cidade, elaborando, então, modelos que permitem reencontrar a ordem alterada pelos avanços da industrialização. Assim, nasce a principal corrente do urbanismo moderno, representada pela proposta progressista, ultrapassando as tendências humanista e naturalista.

A corrente progressista tem sua inspiração no racionalismo filosófico do lluminismo, fundamentando-se em uma concepção abstrata do homem, como sendo mutável no tempo e no espaço; logo, a ciência deve possibilitar a definição exata de um modelo urbano que seja conveniente a todos os grupos humanos. No século XVIII, os clássicos utopistas têm suas preocupações voltadas para uma descrição da cidade ideal, geralmente compreendida como o local de uma melhor organização social. Entre esses pensadores, destacam-se: Fourier, que propõe substituir a cidade pelo falanstério, palácio social onde vivem em comum aproximadamente 1.600 indivíduos, predominando neste imóvel um tipo de via interior, a rua galeria, sobre a qual se abrem os apartamentos; já Owen tem como proposta a fundação de "cidades de harmonia e cooperação", acomodando 1.200 pessoas em conjuntos habitacionais e explorando ao mesmo tempo um domínio agrícola; de forma diversa, Proudhon e Richardson defendem habitações individuais; enquanto Cabet admite uma cidade com plano quadriculado e dotada de um comunismo integral. ${ }^{75}$

Em suma, essas diversas utopias buscam o cuidado com a higiene, tendo como principais metas o verde, a luz, o espaço e a água. Além do mais, também está presente uma repartição do espaço em função das seguintes atividades: residência, trabalho, lazer, com exceção do modelo de Cabet, onde a ruptura com a cidade tradicional é total, sendo substituída

\footnotetext{
74 HAROUEL, 1990, p. 115.

75 Ibid., p. 117.
} 
por unidades de habitação sequenciadas e implantadas sobre um vasto espaço. ${ }^{76}$ Contudo, tais utopias tinham visíveis características compatíveis com sistemas constrangedores e repressivos que se escondiam atrás de fórmulas agradáveis.

No século XIX é observada uma interessante realização criada por Godin em Guise, sob o Segundo Império, que é o familistério - tipo de falanstério composto por três blocos quadrados unidos pelos ângulos, cada um com um corredor coberto de vidro; sendo que, nestes imóveis de quatro níveis, esse proprietário instala seus operários, mas não conserva a vida em comum do falanstério. Em geral, o familistério possui um jardim para lazer e numerosos serviços coletivos: creche, lavanderia, açougue, escola, teatro etc. De modo que, a partir de 1880, Godin transforma sua empresa em uma cooperativa que associa capital e trabalho, tendo como meta criar, segundo a ideia de Fourier, uma comunidade humana autossuficiente e um conjunto arquitetural que corresponda a esse ideal, objetivo esse que foi alcançado graças ao dinamismo econômico de sua empresa.

Ainda na fase do pré-urbanismo, é pertinente lembrar que a grande parte das outras realizações diz respeito à construção de habitações para os operários. Na Inglaterra, por exemplo, a influência de Disraeli é determinante, haja vista que ricos empreendedores fundam, em 1845, uma "sociedade pela melhoria das habitações das classes trabalhadoras"; já em 1851, são discutidas e votadas as primeiras legislações sobre as construções subvencionadas, tendo em 1853 Titus Salt criado para seus operários a cidade-modelo de Saltaire, inspirada nos romances de Disraeli. Concomitantemente, na França, industriais criam para seus operários cidades de casas com jardim, como os Schneiders em Creusit, os Wendels em Stiring. Em Paris, Luís Napoleão Bonaparte funda em 1849 a cidade Napoleão, na Rua de Rochechouart, um conjunto habitacional ao redor de um pátio envidraçado que anuncia Guise; posteriormente, sob o Império, ele acentua sua ação em favor da habitação popular. ${ }^{77}$

Visando afastar-se de seu conteúdo ideológico, as utopias do pré-urbanismo são retomadas pelo patronato e pelos poderes públicos. Mas, com o início do século XX, a corrente progressista chega ao urbanismo moderno com a pretensão de ser uma ciência global da cidade. Nessa conjuntura, em 1901, o arquiteto Tony Garnier elabora um plano da cidade industrial onde se encontra praticamente tudo o que está na base do urbanismo atual. Indiscutivelmente, sua influência é significativa sobre os arquitetos "racionalistas", que criam o "estilo internacional" e elaboram o modelo de urbanismo progressista. Então, a partir de 1928, eles formam o movimento internacional designado pelas iniciais CIAM (Congresso Internacional de Arquitetura Moderna). Já em 1933, os arquitetos do CIAM elaboram um relevante manifesto

\footnotetext{
76 HAROUEL, 1990, p.117.

77 Ibid., p. 118.
} 
doutrinário: a Carta de Atenas $^{78}$, sendo considerado um manual do urbanismo progressista, tendo este documento muitas das ideias de Le Corbusier. Com efeito, esse movimento de arquitetos e urbanistas em Atenas elaborou os princípios básicos do urbanismo modernista, tendo como principal mentor Le Corbusier ${ }^{79}$ que, ao perceber que o centro dos negócios das principais cidades americanas afetava o plano da cidade e era uma consequência direta da industrialização sobre o território, procurou antecipar-se à tendência dos movimentos de capital que definitivamente iriam transformar a paisagem urbana, impondo uma convivência inseparável entre arranha céu e centro de negócios, imaginando assim a cidade-torre, como um programa de trabalho completo.

O urbanismo progressista é completamente voltado para a modernidade, entendendo que a cidade do século XX deve ser de seu tempo, afirmando assim a contemporaneidade com base na racionalidade e austeridade, como também pela não mais aceitação da cidade antiga. De fato, a Carta de Atenas, em seu art.65, estabelece que "os valores arquiteturais devem ser salvaguardados"; sendo que, na realidade, o texto preconiza a conservação de alguns monumentos mais importantes, ao redor dos quais se devem destruir os taudis, ou seja, as casas antigas, o que possibilita a criação de "espaços verdes". Nessa perspectiva, o próprio Le Corbusier propôs para Paris, desde 1925, com seu "plano Voisin", a destruição de quase todo o lado direito do rio. Entretanto, ele consente a conservação, sobre a relva, de alguns monumentos e resquícios arquitetônicos, como, por exemplo, uma mansão tradicional. Diante isso, ele afirma que o "patrimônio universal é respeitado" e mesmo valorizado uma vez que se o aproveita melhor. Logo, a princípio, compreende-se que há nele um modernismo simplista; mas, o essencial em seu pensamento, certamente, é a sua preocupação com a higiene, que se concretiza nas exigências importantes de sol e verde.

A Carta de Atenas exige construções altas, distantes, umas das outras, isoladas no verde e na luz, sendo as torres e as marquises símbolos do teorema higienista. Nesse contexto, ressalte-se o fato de que, ainda que os anglo-saxões e os holandeses se mostrem favoráveis à casa baixa, o imóvel coletivo gigante representa o ideal do urbanismo progressista. Le Corbusier, no "plano Voisin", prevê a substituição do centro de Paris por torres de $200 \mathrm{~m}$ de altura, ocupando somente $5 \%$ da superfície do solo; consequentemente, nesta proposta não há mais espaço urbano, mas unidades autônomas de habitação ou de escritório, cada uma

\footnotetext{
${ }^{78} \mathrm{~A}$ Carta de Atenas é composta de: uma Primeira Parte, que prevê as generalidades relacionadas com a cidade e sua região; uma Segunda Parte, onde aborda o estado atual - crítico das cidades, com as respectivas observações sobre habitação, lazer, trabalho, circulação e patrimônio histórico; e, por fim, apresenta as Conclusões, sob uma perspectiva doutrinária. CARTA DE ATENAS. Assembleia do Congresso Internacional de Arquitetura Moderna - 1933. Trad. Rebeca Scherer. São Paulo: Houcitec/Edusp, 1989.

${ }^{79}$ CORBUSIER, Le. Urbanismo. Trad. Maria Ermantina Galvão. São Paulo: Martins Fontes, 2000. Passim.
} 
concebida como uma pequena cidade vertical. Mas, o Modelo melhor elaborado da unidade habitacional é a denominada "Cidade Radiante" de Le Corbusier, realizada pela primeira vez em Marselha em 1947 e reproduzida em Nantes e Berlim. Em outras palavras, trata-se de um vasto imóvel de 17 andares, previsto para 1.500 ou 2 mil pessoas, constituindo uma versão modernizada e vertical do falanstério com seus serviços coletivos e suas ruas interiores sobre as quais se espalham as habitações.

Um outro teorema do urbanismo progressista é a abolição da rua, denunciada como anacrônica, barulhenta, perigosa, contrária aos imperativos de luminosidade e higiene. A Carta de Atenas exige que os imóveis sejam implantados longe dos fluxos de circulação (art. 27). Ademais, esse modelo progressista fundamenta-se na análise das funções urbanas acompanhadas de um zoning (arts. 77 e 78), distribuindo as funções de habitação, trabalho e lazer em zonas específicas. Assim sendo, tal esquema urbano é considerado válido em qualquer lugar, pois é concebido para o homem-padrão, com bem lembra Corbusier 80 : "todos os homens possuem as mesmas necessidades". De forma que, os urbanistas progressistas aplicam as mesmas soluções no mundo inteiro, tanto para as grandes quanto para as pequenas cidades.

Em sentido contrário, a socióloga Jane Jacobs ${ }^{81}$, analisando os prejuízos do urbanismo e da renovação urbana nos Estados Unidos, demonstra que o abandono da rua acarreta o desaparecimento das principais vantagens da vida urbana: segurança, contato, formação das crianças, diversidade das relações etc. Continuando, esta autora acrescenta que a estrita aplicação do princípio do zoning ${ }^{82}$ causa um esvaziamento diurno nos bairros habitacionais, reforçando assim um sentimento de tédio, que se exacerba diante da padronização

\footnotetext{
${ }^{80}$ BOESIGER, Willy. Le Corbusier. Trad. Júlio Fischer. São Paulo: Martins Fontes, 1994. p. 9.

81 JACOBS, Jane. Morte e vida de grandes cidades. Trad. Maria Estela Helder Cavalheiro. 3.ed. São Paulo: Martins Fontes, 2011. p. 29 et seq. (Coleção cidades). Registre-se que, na mesma perspectiva de Jacobs, Peter Hall apresenta uma história intelectual do planejamento e do projeto urbanos do século XXI, a partir de elementos qualitativos para as cidades: cidade da noite apavorante, cidade no jardim, cidade na região, cidade dos monumentos, cidade das torres, cidade da teoria, cidade do empreendimento, cidade da permanente ralé etc. HALL, Peter. Cidades do amanhã: uma história intelectual do planejamento e do projeto urbanos do século XXI. Trad. Pérola de Carvalho. São Paulo: Perspectiva, 2013.

$82 \mathrm{O}$ urbanismo moderno consolidou o zoning como instrumento fundamental de planejamento, surgindo em uma época em que as forças que controlavam a cidade tinham como finalidade a inversão de capitais e o rendimento mais elevado das habitações de aluguel. Bairros inteiros eram compostos de construções apertadas, sem as mínimas condições de habitabilidade. Mas, esta situação era essencial para o poder acomodar o maior número de pessoas no menor espaço possível, já que não estavam consolidados e popularizados os meios mecânicos de deslocamentos, como o automóvel e o elevador. Assim, ao propor a separação entre comércio e residência, como também o afastamento entre prédios, os zoning leva a abdicação de um modelo intensivo do solo, no qual se baseava a cidade antiga. Cf. DANTAS, Maria Graziela de Almeida. Planejamento urbano e zoning: flexibilidade do modelo de zoning para a competitividade das cidades. João Pessoa: UFPB, 2003. p. 72-73.
} 
arquitetônica. Dessa maneira, para Jacobs o essencial é refazer as ruas ${ }^{83}$, deixando-as vivas, animadas, comerciais, locais de sociabilidade e de segurança.

Na corrente humanista, foi formado o movimento culturalista, que se fundamenta nas ideias de pensadores como Max Weber e Sombart, que partem do entendimento de que a cidade europeia pré-industrial representa um momento histórico especial, possibilitando a partir da vida comunitária a realização individual e a ascensão cultural. Tal movimento surge na Inglaterra do século XIX, sob a influência de Pugin, Ruskin e Morris. Então, estética e cultura ocupavam o mesmo lugar que a higiene em Owen ou Fourier; mas, é, sobretudo, uma ideologia anti-industrialista, nutrida pela clássica nostalgia da cidade do passado, que tem como propósito retomar o calor humano e a qualidade arquitetural. Logo, para essa linha de pensamento, é necessário retornar as pequenas cidades, com limites definidos, ruas sinuosas, adaptadas ao sítio natural. De um modo geral, esses autores entendem que "o aspecto desagradável" encontrado na sociedade industrial advém de uma carência cultural que pode ser enfrentada por meio do retorno a uma arte inspirada na Idade Média, em associação com o renascimento de um artesanato.

Max Weber ${ }^{84}$, ao analisar a tipologia das cidades, enfatiza a influência do mercado sobre as diversas formas de cidades: de funcionários, de rentistas, de consumidores, de produtores, mercantil, fortaleza, entre outras. Além do mais, esse autor desenvolve uma ampla explanação sobre a formação da cidade no Ocidente, a cidade de linhagem na Idade Média e na Antiguidade e a cidade plebeia; tudo isso em uma clara demonstração do predomínio que tem o paradigma da racionalidade científica-instrumental na sociedade capitalista.

No final do século XIX, o movimento culturalista chega ao campo do urbanismo propriamente dito, com os princípios do planejamento das cidades sendo estudados cuidadosamente pelo arquiteto alemão Sübben, que publica em 1880 seu Städtebau, tratado de construção das cidades. Em síntese, ele reúne as lições das falhas cometidas por seus predecessores, quando quiseram sobrepor uma cidade moderna a uma antiga; de forma que, ele apresenta a proposta de respeitar o passado, construindo a cidade nova ao lado da antiga. Por sua vez, o urbanista austríaco Sitte denuncia a mediocridade da cidade moderna e procura extrair de um estudo minucioso sobre as cidades antigas os princípios que devem inspirar os responsáveis pela criação e expansão das cidades, com o objetivo de adotar um procedimento

83 Encontramos no trabalho de Berman, uma importante abordagem sobre o modernismo nas ruas a partir de Baudelaire. De igual modo, a cidade Petersburgo é tomada para análise do modernismo no âmbito do subdesenvolvimento, nos séculos XIX e XX, sempre tomando como referência as ruas. BERMAN, 1986.

${ }^{84}$ WEBER, Max. Economia e sociedade: fundamentos da sociologia compreensiva. Trad. Regis Barbosa; Karen Elsabe Barbosa. Brasília: UnB, 1990. p. 408 et seq. 
consciente de soluções intuitivas que obtiveram êxito nas diferentes épocas "onde o respeito da arte era uma tradição". ${ }^{85}$

$\mathrm{Na}$ Inglaterra, o urbanismo culturalista adquire uma nova direção com Howard e seu projeto de cidade-jardim ${ }^{86}$, exposto em 1898 em um livro intitulado To morrow. Este urbanista procurou reunir as vantagens da cidade e não um subúrbio difuso desprovido de centro e de limites. Então, concebido para 32 mil habitantes, o projeto de Howard possui uma distinção nítida entre os 400 hectares urbanos e o cinturão verde agrícola de dois mil hectares que os contorna. O espaço urbano compreende, no centro, uma área comercial e administrativa; depois, uma zona anular destinada às habitações, cada um provida de seu jardim. Assim sendo, a proposta é uma zona industrial na periferia, objetivando impedir a especulação fundiária, com a comunidade de habitantes sendo proprietária do solo urbano. ${ }^{87}$

Por sua vez, a corrente do urbanismo antropológico se propõe a resolver o problema da criação e do planejamento das cidades por meio das informações fornecidas pela antropologia descritiva. Inicialmente, foi o escocês Geddes quem seguiu essa linha de pensamento, orientando-se para o urbanismo nos primeiros anos do século. Na concepção deste urbanista, a origem de uma cidade é decorrente da continuidade histórica de uma dada civilização, argumentando que para se fazer uma cidade é necessário conhecer as necessidades e as aspirações da mesma. Além disso, esse biólogo defende uma ampla investigação que alcance aspectos geográficos, históricos, econômicos, sociológicos, estéticos, entre outros; tudo isso por intermédio do método sociogical surveys. Em seguida, é utilizado o Town-planner, tendo assim reunido todas as informações possíveis que lhe permitam conceber as soluções urbanísticas adaptadas à cidade ou ao bairro a criar.

Lewis Mumford, americano discípulo de Geddes, acompanha todo o avanço do urbanismo progressista, do qual ele não cessa de denunciar o caráter arbitrário. Em linhas gerais, Mumford ${ }^{88}$ se propõe a reintroduzir nas sociedades urbanas o ambiente comunitário e o calor humano da cidade medieval, por meio de um sistema pluridimensional urbano na perspectiva de uma cidade regional ${ }^{89}$; ou seja, seria um sistema unindo cidade e campo em um vasto conjunto, sendo isso em escala regional e com múltiplos centros, mas sempre

85 HAROUEL, 1990, p. 122-123.

86 Encontramos essa perspectiva no trabalho de Wendel Henrique, onde este autor desenvolve uma abordagem sobre a incorporação da natureza à vida social, enfocando a importância da presença da natureza na cidade e nos empreendimentos imobiliários. Cf. HENRIQUE, Wendel. O direito à natureza na cidade. Salvador-BA: EDUFBA, 2009.

87 HAROUEL, 1990, p.123.

88 MUMFORD, 2008, passim.

89 Sobre essa perspectiva, ver o trabalho de Mumford, onde há uma discussão sobre a estrutura regional da civilização. MUMFORD, Lewis. A cultura das cidades. Trad. Neil R. da Silva. Belo Horizonte: Itatiaia, 1961. p. 318 et seq. 
funcionando como um todo. Para esse autor, essa nova forma de estruturação urbana conservaria as vantagens das pequenas aglomerações, ao mesmo tempo em que rivalizaria com as grandes metrópoles, devido aos recursos e possibilidades de ação.

Por fim, a corrente naturalista, que é própria aos Estados Unidos, se forma no século XIX, a partir de uma forte tradição antiurbana ligada à imagem nostálgica de uma natureza virgem e ao mito dos pioneiros. Já no século XX, essa ideologia converge para um urbanismo antiurbano, sob o impulso do arquiteto F. L. Wright. Mas, muito embora intitulado BroadacreCity, seu projeto contém uma total dissolução das funções urbanas na natureza, visto que prevê apenas habitações individuais, tendo cada uma, no mínimo, dois hectares. Ademais, as atividades profissionais são geralmente anexadas à habitação ou agrupadas em pequenos centros isolados. Enfim, todas essas implantações pontuais são ligadas entre si por uma importante rede terrestre, bem como por via aérea; de forma que esse foi o modelo urbanístico concebido por Wright para assegurar a felicidade do indivíduo que seria, segundo ele, indissociável da posse de uma parcela da natureza suficientemente vasta.

\section{CONSIDERAÇÕES FINAIS}

Ao término deste trabalho, foi verificado que com a chegada do progresso técnico e da civilização industrial, a visão tradicional é superada, multiplicando-se assim os problemas com os quais uma cidade se depara: crescimento demográfico, condições de habitação da população e, sobretudo, enriquecimento de determinados extratos sociais, que se traduz pelo fato de se beneficiarem com numerosos objetos materiais e espaços cada vez mais significativos, bem como de uma quantidade crescente de prestação de serviços. Logo, concluímos que é a partir da cidade industrial que é possível compreender as condições próprias da realidade contemporânea, bem como se tornam perceptíveis os seus antecedentes, a saber: a sociedade comercial que, por sua vez, permite apreender a cidade política à qual se superpôs.

No decorrer deste estudo, observamos que a inserção na sociedade urbana e as modalidades de urbanização dependem das particularidades da sociedade considerada no curso da industrialização (capitalista ou socialista, em desenvolvimento econômico ou tecnologicamente avançado). Com efeito, as diferentes formas de entrada na sociedade urbana, com suas implicações e consequências, fazem parte da problemática denominada fenômeno urbano, sendo esta terminologia utilizada por algumas correntes teóricas como sinônimo da palavra "cidade", por entenderem que esta expressão designa um objeto definido e definitivo, dado para a ciência como objetivo imediato de ação; em outras palavras, para essa perspectiva 
de pensamento, não há uma ciência da cidade, e sim um conhecimento que envolve constantes formações e transformações do processo global urbano.

Foi também concluído que a cidade, como fenômeno dinâmico e complexo, é um espaço de constantes transformações, pois ela possui a capacidade de articular objetivamente inúmeros fatores sociais, não se limitando apenas ao seu território propriamente dito. De fato, considerando que a cidade é estruturada por processos contraditórios, logo, ela deve ser entendida como uma totalidade de permanentes transformações, visto que as modificações que acontecem em locais específicos podem desencadear mudanças em outras áreas. Portanto, as singularidades das cidades implicam em constantes transformações na apreensão de sua totalidade, intermediadas pelos processos de trabalho que envolvem inúmeras pessoas e instituições.

Outrossim, observamos que a dinâmica da estrutura interna da cidade pode ser consequência tanto da implantação de equipamentos coletivos (escolas, hospitais, conjuntos habitacionais, centros comerciais, entre outros), quanto de aspectos que só podem ser explicados socialmente, como é o caso da exclusão e segregação espacial advindas da localização de determinados grupos populacionais identificados pelas diferenças do poder aquisitivo, decorrentes das desigualdades sociais ainda presentes na sociedade contemporânea.

É necessário frisarmos que, no decorrer do levantamento realizado sobre o desenvolvimento das cidades, partindo da antiguidade e chegando as cidades dos dias atuais, observamos a necessidade da contextualização histórica das cidades brasileiras. Então, percebese que o modelo de cidade inspirado na concepção medieval europeia, trouxe uma série de problemas ambientais para a cidade colonial brasileira, visto que o traçado da cidade medieval, embora estivesse integrado ao clima temperado ou frio da Europa, com suas ruas sinuosas dificultando a penetração do vento e do frio, no Brasil, diferentemente, a transposição direta da mesma configuração urbana se revelou em um equívoco, devido as condições climáticas com características opostas, onde o vento exerce o papel de amenizar o calor tropical.

Em geral, na organização da cidade colonial brasileira, prevaleceram os valores estéticos, ideológicos e econômicos sobre os aspectos naturais (climáticos), com grande prejuízo para a qualidade ambiental urbana; sendo que, esse modelo de cidade predominou na paisagem urbana durante séculos, influenciando até os dias atuais o padrão de qualidade ambiental da população brasileira. Em resumo, é possível afirmar que foram os fatores econômicos e tecnológicos relacionados com o modo de produção e desenvolvimento que influenciaram a forma da cidade xadrez, haja vista que esta forma de planejamento urbano tem a característica principal de facilidade para implementação, comercialização e expansão, 
enquanto que os aspectos naturais tinham uma importância secundária nessa fase de organização urbana.

O estudo do urbanismo presente desde o início da era industrial nos possibilitou verificar que houve uma predominância da corrente progressista, tendo em vista que o urbanismo naturalista se limitou apenas em alguns bairros suburbanos dos Estados Unidos. Já o urbanismo culturalista, exerce uma certa influência na Inglaterra com a formação de novas cidades. Mas, sem dúvida, o urbanismo progressista encontra-se presente em toda parte, qualquer que seja o regime político ou nível de desenvolvimento econômico. Dentre suas grandes realizações, destacamos a criação de Chandigarh, a partir dos planos de Le Corbusier; Brasília, com os projetos de Oscar Niemeyer, entre outras grandes obras; registre-se que, encomendadas por seus presidentes Nehru e Kubitschek, respectivamente, constituem grandiosas manifestações do urbanismo e da estética progressistas. Mais especificamente, grandes edifícios públicos que ocupam enormes espaços vazios constituem uma escultura urbana de inspiração cubista, a partir de volumes geométricos simples; por exemplo, em Brasília, os bairros habitacionais não diferem muito dos grandes conjuntos habitacionais que se encontram nos subúrbios tanto de Paris quanto de Moscou.

Constatamos igualmente que o modelo urbanístico progressista dominante, nos dias atuais, é amplamente contestado, pois, concomitantemente, a cidade saída do passado, contra a qual foram dirigidas críticas por parte do organismo progressista, é objeto de reabilitação neste século XXI. A refutação ao urbanismo progressista tem como principais críticas: ser um urbanismo desumano, onde surgem as noções de caixas de habitação e o concreto que invade e agride a cidade antiga; entrave para a volta de uma concepção mais tradicional da cidade, com ruas, pedestres, lojas, oficinas e, enfim, a presença de relações e interações sociais cotidianas. Em suma, a ampla aplicação do princípio do zoning, esvazia os bairros habitacionais durante o dia, exteriorizando a solitária e fria padronização da arquitetura, tendo como resultados ruas desertas de cidades-dormitórios.

De um modo geral, os resultados obtidos pelo urbanismo moderno são discutíveis, apesar de ter uma amplitude predominante, em virtude das possibilidades pelos meios técnicos que a sociedade industrial coloca à disposição dos arquitetos, dos engenheiros e dos urbanistas, conseguindo, de certa forma, alojar um determinado contingente populacional. Mas, por outro lado, a proposta progressista não prova que as vias utilizadas são as únicas nem as melhores, tendo em vista que constituem uma negação da cidade tradicional; além de que, quanto ao espaço rural, ele é simplesmente abandonado no percurso natural de uma urbanização difusa, que toda uma geração descaracteriza com construções esdrúxulas. De maneira que, finalizamos 
este trabalho alertando para o fato de que a preservação, que ainda nos resta das paisagens e dos sítios, deverá constituir uma das tarefas prioritárias do urbanismo atual e futuro.

Enfim, esperamos que este texto venha a contribuir para as discussões sobre a formação, estrutura e transformações das cidades. Ademais, alertamos também para a relevância que têm os planejamentos urbanos para o conjunto da cidade, incluindo, evidentemente, as populações de comunidades mais carentes que estão presentes em praticamente todas as cidades brasileiras.

\section{REFERÊNCIAS}

ARISTÓTELES. A política. Trad. Nestor Silveira Chaves. 2. ed. Bauru-SP: EDIPRO, 2009.

BAUDRILLARD, Jean. A sociedade de consumo. Trad. Artur Morão. Lisboa: Edições 70, 1970.

BEAUJEAU-GARNIER, Jacqueline. Geografia urbana. Lisboa: Calouste Gulbenkian, 1980.

BENOVOLO, Leonardo. História da cidade. São Paulo: Perspectiva, 1983.

BERMAN, Marshall. Tudo que é sólido desmancha no ar: a aventura da modernidade. Trad. Carlos Felipe Moisés; Ana Maria L. Ioriatti. São Paulo: Companhia das Letras, 1986.

BOESIGER, Willy. Le Corbusier. Trad. Júlio Fischer. São Paulo: Martins Fontes, 1994.

BONINI, Roberto. Noção de polis. In: BOBBIO, Norberto; et al. Dicionário de política. Brasília: UNb, 1986.

CARTA DE ATENAS. Assembleia do Congresso Internacional de Arquitetura Moderna - 1933. Trad. Rebeca Scherer. São Paulo: Houcitec/Edusp, 1989.

COELHO, Claudio Novaes Pinto; CASTRO, Valdir José de. (Orgs.). Comunicação e sociedade do espetáculo. São Paulo: Paulus, 2006.

COELHO, Teixeira. Moderno, pós-moderno: modos e versões. 4.ed. São Paulo: Iluminuras Ltda, 2001.

CORBUSIER, Le. Urbanismo. Trad. Maria Ermantina Galvão. São Paulo: Martins Fontes, 2000.

CORRÊA, Roberto Lobato. O espaço urbano. São Paulo: Ática, 1989.

COULANGES, Fustel de. A cidade antiga. Trad. Jean Melville. 2.ed. São Paulo: Martin Claret, 2007.

DANTAS, Maria Graziela de Almeida. Planejamento urbano e zoning: flexibilidade do modelo de zoning para a competitividade das cidades. João Pessoa: UFPB, 2003.

DELEUZE, Gilles. Foucault. Trad. Cláudia Sant'Anna Martins. São Paulo: Brasiliense, 2005. 
ELIAS, Norbert. Estalecidos e outsiders: sociologia das relações de poder a partir de uma pequena comunidade. Trad. Vera Ribeiro. Rio de Janeiro: Zahar, 2000.

FERREIRA, Waldemar Martins. História do direito brasileiro. Tomo I. Rio de Janeiro: Freitas Bastos. 1951.

FESTUGIÈRE, A. J. La révélation d’Hermès Trismégiste: le dieu cosmique. Paris: [s.n.], 1949.

FREITAG, Barbara. Teorias da cidade. Campinas-SP: Papirus, 2006.

GARCIA, Maria. A cidade e o Estado: políticas públicas e o espaço urbano. In:

(Coord.). A cidade e seu Estatuto. São Paulo: Juarez de Oliveira, 2005.

GOUVÊA, Luiz Alberto. Biocidade:conceitos e critérios para um desenho ambiental urbano, em localidades de clima tropical de planalto. São Paulo: Nobel, 2002.

HALL, Peter. Cidades do amanhã: uma história intelectual do planejamento e do projeto urbanos do século XXI. Trad. Pérola de Carvalho. São Paulo: Perspectiva, 2013.

HAROUEL, Jean-Louis. História do urbanismo. Trad. Ivone Salgado. Campinas/SP: Papirus, 1990.

HARVEY, David. Condição pós-moderna. Trad. Adail Ubirajara Sobral; Maria Stela Gonçalves. 12.ed. São Paulo: Loyola, 2003.

HENRIQUE, Wendel. O direito à natureza na cidade. Salvador-BA: EDUFBA, 2009.

HOLANDA, Sérgio Buarque de. Raízes do Brasil. 26.ed. São Paulo:Companhia das Letras, 1995.

HOUAISS, Antônio; VILLAR, Mauro de Sales. Dicionário Houaiss da Língua Portuguesa. Rio de Janeiro: Objetiva, 2001.

JACOBS, Jane. Morte e vida de grandes cidades. Trad. Maria Estela Helder Cavalheiro. 3.ed. São Paulo: Martins Fontes, 2011.

JONAS, Hans. O princípio responsabilidade: ensaio de uma ética para a civilização tecnológica. Trad. Marijane Lisboa; Luiz Barros Montez. Rio de Janeiro: Contraponto, 2006.

KALINA, Eduardo; KOVADLOFF, Santiago. As ciladas da cidade. Trad. Eduardo Kovadloff. São Paulo: Brasiliense, 1978.

KITTO, H. D. F. The Greeks: a study of the character and history of an ancient civilization, and of the people who created it. [s.l.]: Pelican Books, 1951.

KUMAR, Krishan. Da sociedade pós-industrial à pós-moderna: novas teorias sobre o mundo contemporâneo. Trad. Ruy Jungmann. Rio de Janeiro: Zahar, 1997.

LEFEBVRE, Henri. A revolução urbana. Trad. Sérgio Martins. Belo Horizonte: UFMG, 2008.

LIRA, Ricardo Pereira. Elementos de direito urbanístico. Rio de Janeiro:Renovar, 1977. 
MARICATO, E. As ideias fora do lugar e o lugar fora das ideias: planejamento urbano no Brasil. In: ARANTES, O; VAINER, C. A cidade do pensamento único: desmanchando consensos. 5. ed. Petrópolis: Vozes, 2009.

Habitações e cidade. São Paulo: Atual, 1990.

MARX, Karl.. Manuscritos econômicos-filosóficos e outros textos escolhidos: para a crítica da economia política. Trad. José Carlos Bruni; et al. v.1. 4.ed. São Paulo: Nova Cultural, 1987.

Manuscritos econômicos-filosóficos e outros textos escolhidos: salário, preço e lucro. Trad. Leandro Konder. v.2. 4.ed. São Paulo: Nova Cultural, 1988.

MOTES, Juan Maluquer de. O nascimento da vida urbana. [s.l.: s.d.], 1975.

MUMFORD, Lewis. A cidade na história: suas origens, transformações e perspectivas. Trad. Neil R. da Silva. São Paulo: Martins Fontes, 2008.

A cultura das cidades. Trad. Neil R. da Silva. Belo Horizonte: Itatiaia, 1961.

PLATÃO. As Leis, incluindo Epinomis. Trad. Edson Bini. 2.ed. Bauru/SP: EDIPRO, 2010.

RONCAYOLO, M. La ville et ses territoires. Paris: Gallimard, 1990.

SANDRONI, P. Dicionário de economia. São Paulo: Best Seller, 1989.

SASSEN, Saskia. As cidades na economia mundial. São Paulo: Nobel, 1996.

SAINT-HILAIRE, Auguste de. Viagens às nascentes do Rio São Francisco e pela província de Goiás. Tomo II, v.78. São Paulo: Cia. Editora Nacional, 1937.

SILVA, José Afonso. Direito Urbanístico Brasileiro. 2.ed. São Paulo: Malheiros, 1997.

SÓFOCLES. A trilogia tebana. Édipo Rei, Édipo em Colono e Antígona. Trad. Mário da Gama Kury. 10.ed. Rio de Janeiro: Zahar, 2004.

SPOSITO, Eliseu Savério. Redes e cidades. São Paulo: UNESP, 2008.

REIS, F. Quadro da arquitetura no Brasil. São Paulo: Perspectiva, 1970.

VILLAS BOAS, Márcio. Significado da arquitetura nos trópicos: um enfoque bioclimático. In: Boletim do Instituto de Arquitetura e Urbanismo. Brasília: UnB, 1986.

WEBER, Max. Economia e sociedade: fundamentos da sociologia compreensiva. Trad. Regis Barbosa; Karen Elsabe Barbosa. Brasília: UnB, 1990.

Trabalho enviado em 19 de setembro de 2014.

Aceito em 04 de fevereiro de 2015. 